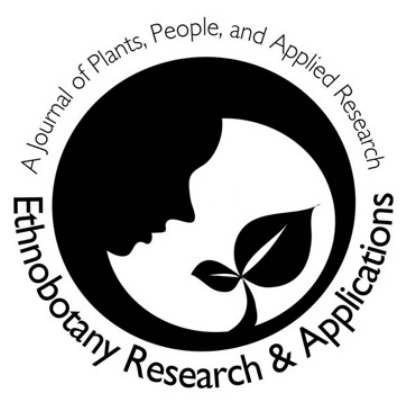

\title{
Ethnoveterinary and fodder plants used among transhumant communities around Georgia-Turkey border, in the Western Lesser Caucasus
}

\author{
Ceren Kazancı, Soner Oruç and Marine Mosulishvili
}

\section{Research}

\begin{abstract}
Background: Livestock are an integral part of the transhumant life in the Caucasus. Maintaining the health and wellbeing of the animals has been a critical responsibility for pastoral communities. This study presents the wild plant species used for ethnoveterinary and fodder purposes by transhumant people on the both sides of GeorgiaTurkey border.
\end{abstract}

Methods: During two summers (2017-2018), 119 participants were interviewed (74 in Turkey and 45 in Georgia) with semi-structured questionnaires. Cultural importance index (Cl) and Relative frequency of citation (RFC) were used to evaluate the relative importance of species among communities.

Results: In total 113 citations of 38 wild plant species for ethnoveterinary purposes, and 186 citations of 61 wild plant species as fodder were obtained in the study area. The most important species in ethnoveterinary were Veratrum album and Achillea millefolium in Georgia, and Veratrum album and Picea orientalis in Turkey. Aerial parts of the plants were the most frequently used part in Georgia while the root was in Turkey. Gastrointestinal problems were the most commonly mentioned diseases in Georgia while dermatological and parasitic diseases in Turkey. The majority of the plant species were mentioned to treat the ailments of cattle (37 species). Fabaceae, Polygonaceae and Asteraceae were the most mentioned families used as fodder in both countries. There were also several plants used as bedding for livestock and against evil eye in the study area.

Conclusions: Pastoral way of life in the Western Lesser Caucasus still reflects living evidence of plant-based traditional ethnoveterinary knowledge and practices to support the health of livestock. The results of this study could be a base for future ethnoveterinary and animal feed research and contribute to organic animal husbandry in the region.

Keywords: Ethnoveterinary, Fodder plants, Transhumant people, Traditional knowledge, the Caucasus, Cross-cultural study, Turkey, Georgia

\section{Correspondence}

Ceren Kazanc $1^{1^{*}}$, Soner Oruç ${ }^{2}$, Marine Mosulishvili ${ }^{1}$

'School of Natural Sciences and Medicine, llia State University, Tbilisi 0162, Georgia

${ }^{2}$ Faculty of Forestry, Artvin Çoruh University, Seyitler Yerleşkesi, Artvin 08100, Turkey

"Corresponding Author:

ceren.kazanci.1@iliauni.edu.ge

Ethnobotany Research \& Applications

21:28 (2021) 


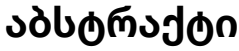

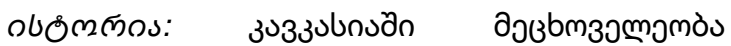

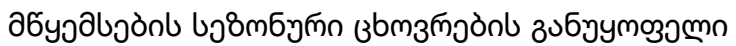

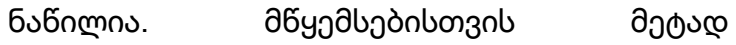

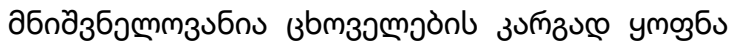

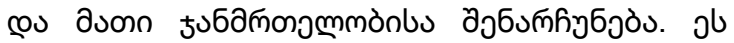

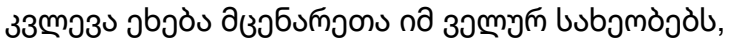

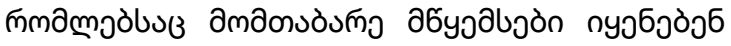

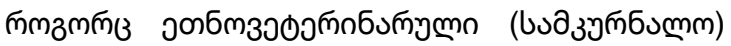

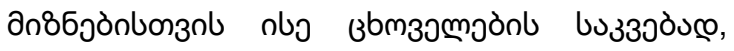

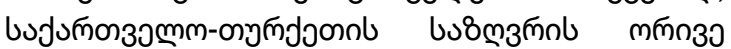
absmol.

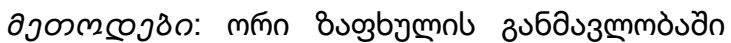

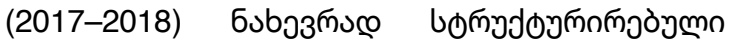

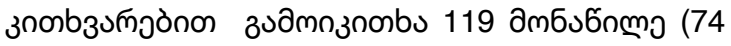

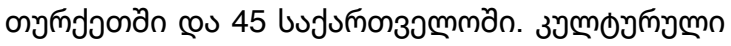

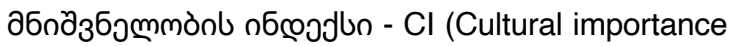

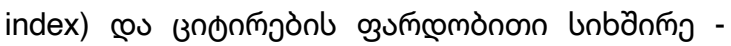

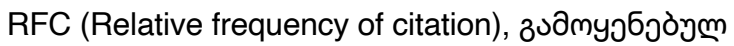

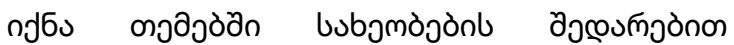

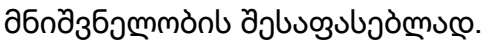

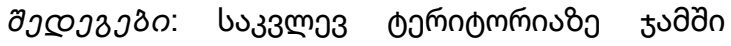

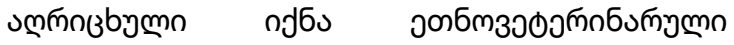

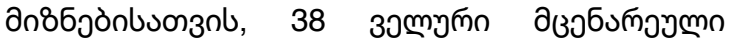

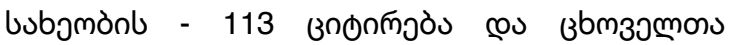

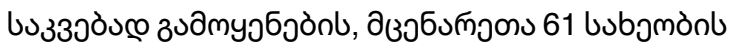

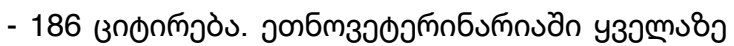

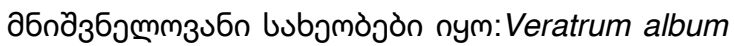

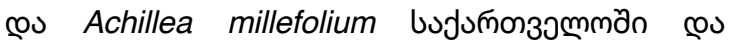

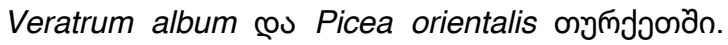

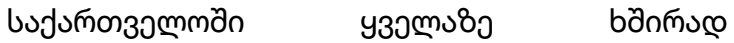

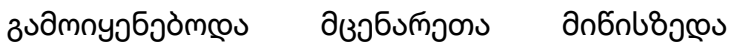

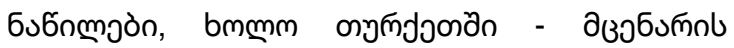

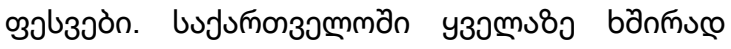

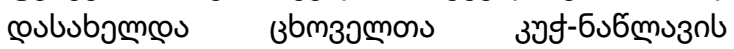

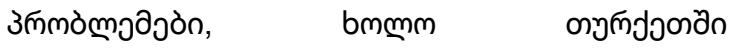

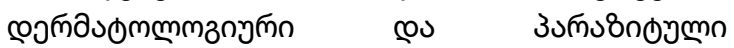

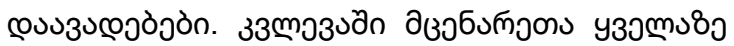

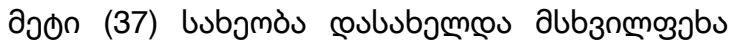

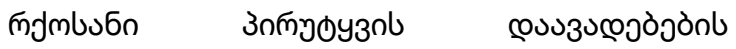

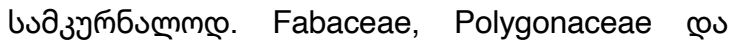

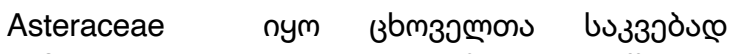

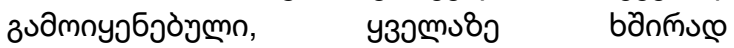

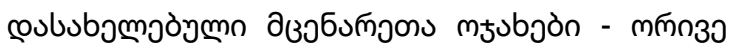

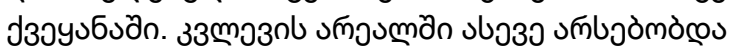

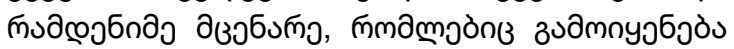

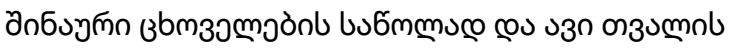

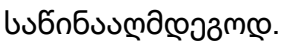

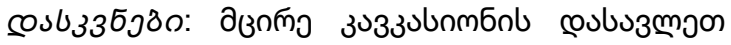

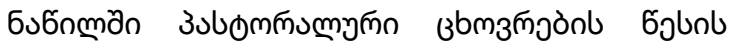

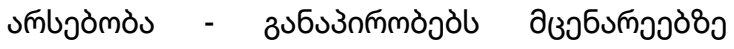

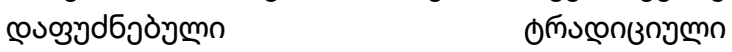

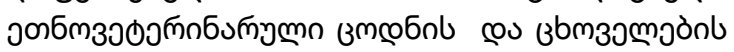

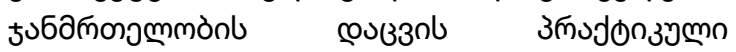

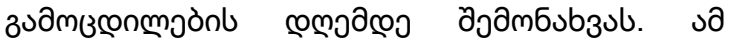

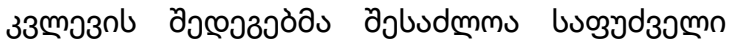

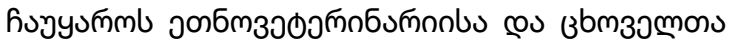

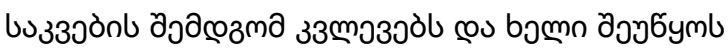

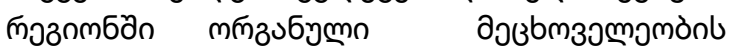

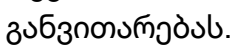

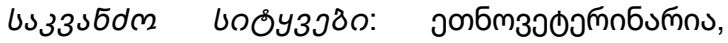

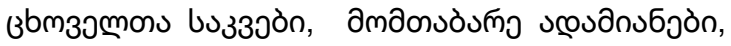

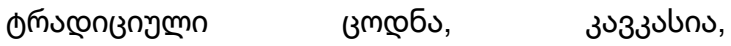

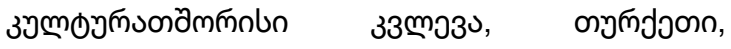

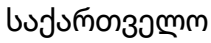

\section{Özet}

Giriş: Kafkaslar'da hayvancılık yaylacıların yaşamının ayrıımaz bir parçasıdır. Yaylacı toplumlar için hayvanların sağlığını ve refahını korumak son derece önemli bir sorumluluktur. Bu çalışma, Gürcistan-Türkiye sınırının her iki yakasında yaşayan yaylacıların halk veterinerliğinde (etnoveterinerlik) ve hayvan yemi olarak kullandıkları yabani bitki türlerini sunmaktadır.

Yöntemler: 2017 ve 2018 yıllarının yaz aylarında 119 katılımcıyla (Türkiye'de 74 ve Gürcistan'da 45) yarı yapılandırılmış görüşmeler gerçekleştirildi. Bilgisi alınan yabani türlerin yaylacı toplumlar arasındaki önemini değerlendirmek için Kültürel Önem (Cl) ve Göreceli Kayıt Sıklığı (RFC) indeksleri kullanıldı.

Bulgular: Çalışma alanında etnoveteriner amaçı 38 yabani bitki türüne ait 113, yem olarak 61 yabani bitki türüne ait 186 kullanım kaydedildi. Hayvan hastalıklaında kullanılan en önemli türler olarak Gürcistan'da Veratrum album ve Achillea millefolium, Türkiye'de ise Veratrum album ve Picea orientalis tespit edildi. Gürcistan'da bitkilerin daha çok toprak üstü kısımları. Türkiye'de ise köklerinin kullanımı bildirildi. Gürcistan'da en çok sindirim sistemi ile ilgili sorunlar bildirilirken, Türkiye'de deri ve paraziter hastalıklar kaydedildi. Kayıt altına alınan yabani bitki türlerinin çoğunun büyükbaş hayvanların (37 tür) rahatsızlıklarında kullanıldığı tespit edildi. Her iki ülkede de Fabaceae, Polygonaceae ve Asteraceae yem olarak kullanımı en çok bahsedilen ailelerdir. Çalışma alanında ayrıca hayvanların altına yataklık olarak serilen ve nazara karşı kullanılan birkaç bitki türü de kayıt altına alındı.

Sonuçlar: Bu çalışma, Batı Küçük Kafkasya'daki yayla yaşamında hayvanların sağlığını destekleyen bitki temelli halk veterinerliği bilgi ve uygulamalarının sürdürüldüğünün kanıtlarını yansıtmaktadır. Çalışmanın sonuçları, gelecekteki halk veterinerliği (etnoveterinerlik) ve hayvan yemi araştırmalarına temel oluşturabilir ve bölgedeki organik hayvancılığa katkı sağlayabilir. 
Anahtar Kelimeler: Halk veterinerliği, Yem bitkileri, Yaylacılar, Geleneksel bilgi, Kafkasya, Kültürler arası çalışma, Türkiye, Gürcistan

\section{Background}

Livestock are an integral part of the transhumant life in the Caucasus and beyond. Maintaining and restoring the health and wellbeing of the animals has been a critical responsibility for the pastoralist communities who depended on their livestock.

Ethnoveterinary research is defined as the systematic study and application of folk knowledge and beliefs, practices that relate to any aspects of animal health (McCorkle 1986). There has been a growing interest in ethnoveterinary research in Europe (Mayer et al. 2014 and the references there in). This is mainly due to concerns for traditional knowledge loss, increase in antibiotic use which result in occurrence of antibiotic-resistant microbes and antimicrobial resistance both in livestock and humans, as well as potential health benefits of traditional veterinary practices on organic animal husbandry (Benítez 2012, Bartha et al. 2015, Mayer et al. 2014, Oliveira et al. 2020, Pieroni et al. 2004, 2006).

Although the studies on folk veterinary knowlege in Turkey is not new (Dinçer 1967\&1980), ethnoveterinary research specific to plant-based remedies is an emerging field of study among veterinary physicians (Özen \& Doğan 2017, Sinmez et al. 2018, Sinmez \& Yaşar 2017, Yipel et al. 2017). Majority of the information on plant-based ethnoveterinary medicine in Turkey has been presented in ethnobotanical research (Erarslan \& Kültür 2019 and the references there in). A recent review on ethnoveterinary plants highlighted a rich diversity of knowledge with 251 plant taxa used as animal medicine in Turkey (Erarslan \& Kültür 2019). Similarly, ethnobotanical studies in Georgia also reported at least 75 plant species used as animal medicine and fodder (Bussmann 2017, Bussmann et al. 2016a, 2016b, 2017, 2018, 2020a, 2020b). However, more research is needed to reveal the full potential of the ethnoveterinary knowledge and practices in the Caucasus before they disappear.

The aims of this study were to document the wild plants used as livestock medicine and fodder by transhumant people living around Georgia-Turkey border; to evaluate the similarities and difference in ethnoveterinary knowledge and practices on both sides of the border; to compare the results of this study with the literature.

\section{Material and Methods Study area}

The geographical area covered in this study is located along the border between Georgia and Turkey, in the Western Lesser Caucasus (Fig. 1). It falls within the borders of Adjara and SamtskheJavakheti regions in Georgia; and Artvin and Ardahan provinces in Turkey.

The area includes the characteristics of three of the world's ecological regions: The Caucasus Mixed Forest Ecoregion, the Euxine Colchic Deciduous Forest Ecoregion and, to a lesser extent, the Eastern Anatolian Montane Steppe Ecoregion (WWF 2006). Its principal climates range from humid subtropical and mildly dry subtropical mountainous to continental climates. Dominant natural landscapes extend from forest and high mountain vegetation to Caucasian sub-alpine meadows and steppe meadows with freshwater lakes, mainly located along the Ardahan and the Samtskhe-Javakheti border (Williams et al. 2006) (Fig. 2). The variety of ethnolinguistic groups inhabiting the area includes Turks, Georgians, Armenians, Kurds, Azeris, Laz people, Hemshins, and Russians, with small-scale agriculture and relatively large-scale livestock farming as their main economic activities. Nearly all participants in this study were transhumant, maintaining an agro-pastoral way of life. Highland pastures, referred to as "yayla" in Turkey, are known as " $m t a "$ and/or "ialagi" (iala) in Georgia. People move to their summer pastures at the end of May, where for three to five months they live mainly in wooden houses, with some living in dry stone dwellings or even tents.

\section{Ethnobotanical data collection}

In the summer of 2016, two weeks of non-systematic preliminary fieldwork were conducted, with the undertaking of informal interviews in 20 highland pastures and villages in Georgia and Turkey (Oruç \& Kazancı 2018). Over the following two summers (2017-2018), a total of around 90 days of systematic fieldwork were carried out during the period of transhumance (approximately June 15 - September 15), visiting 102 highland pastures, 65 in Turkey and 37 in Georgia (Fig. 1). During that time, 119 participants were interviewed 74 in Turkey (41 women; 33 men), and 45 in Georgia (28 women; 17 men). The mean ages of participants were 57 (from 25 to 85 ) in Georgia and 58 (from 25 to 95) in Turkey.

A snowball technique was used to find participants who held significant traditional knowledge regarding wild plants and their usage. The majority of the participants were elderly transhumant people. Each participant was interviewed individually, for an 
average of two hours, with semi-structured questionnaires. Usually, the person's relatives and neighbors also contributed to the interview. In Turkey mother languages of the participants were Turkish, Georgian, Laz, Homshetsi or Kurdish. We conducted the interviews in Turkish. In Georgia, mother languages of the participants were Georgian, Armenian, Russian or Azeri. Here, interviews were conducted in Georgian, Russian, or Turkish with the help of translators.

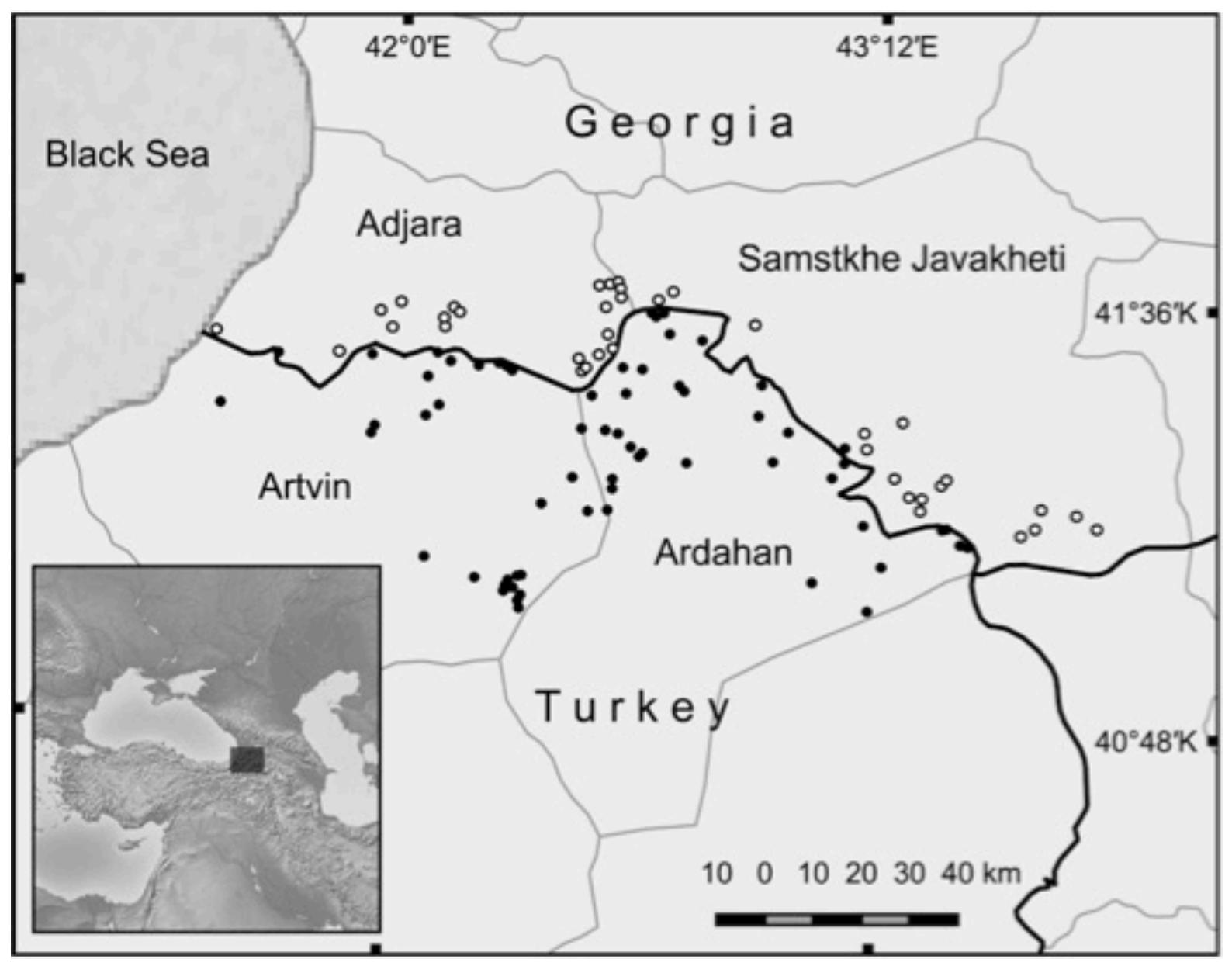

Figure 1. Map of study area showing the distribution of visited highland pastures and villages. Black dots correspond to places in Turkey; white dots refer to places in Georgia. (Map generated by Ceren Kazancı using QGIS)

The first author took notes directly in a notebook during all interviews. Depending on the participants' wishes, audio or video recordings were made of the interviews. Information about plants collected from the wild was documented, specifically with data regarding their folk names in different languages and dialects, collection time and place, parts used, purpose of use, processes of preparation, and sources of plant knowledge. In addition, observations were made, and photos were taken in byres, cellars and other relevant places whenever possible, so as to document unmentioned uses and also observe living ethnobotanical practices.

Initially, participants were asked to discuss points about wild plants that immediately came to mind $(\sim 15$ min). Then they were shown fresh plants and asked to identify the vernacular names and usage of the plants ( 45 min). Depending on the weather and participants' willingness, a "walk around the house" was undertaken to observe wild plants in the vicinity ( 15 min). To confirm previous information and to gain further learning about various plants, participants were shown an illustrated plant catalogue, including 400 plant species from the flora of the region ( $45 \mathrm{~min}$.). Certain participants were visited a second time to complete the first interview or to confirm information. All interviews conformed to the International Society of Ethnobiology's Code of Ethics (ISE 2008). 

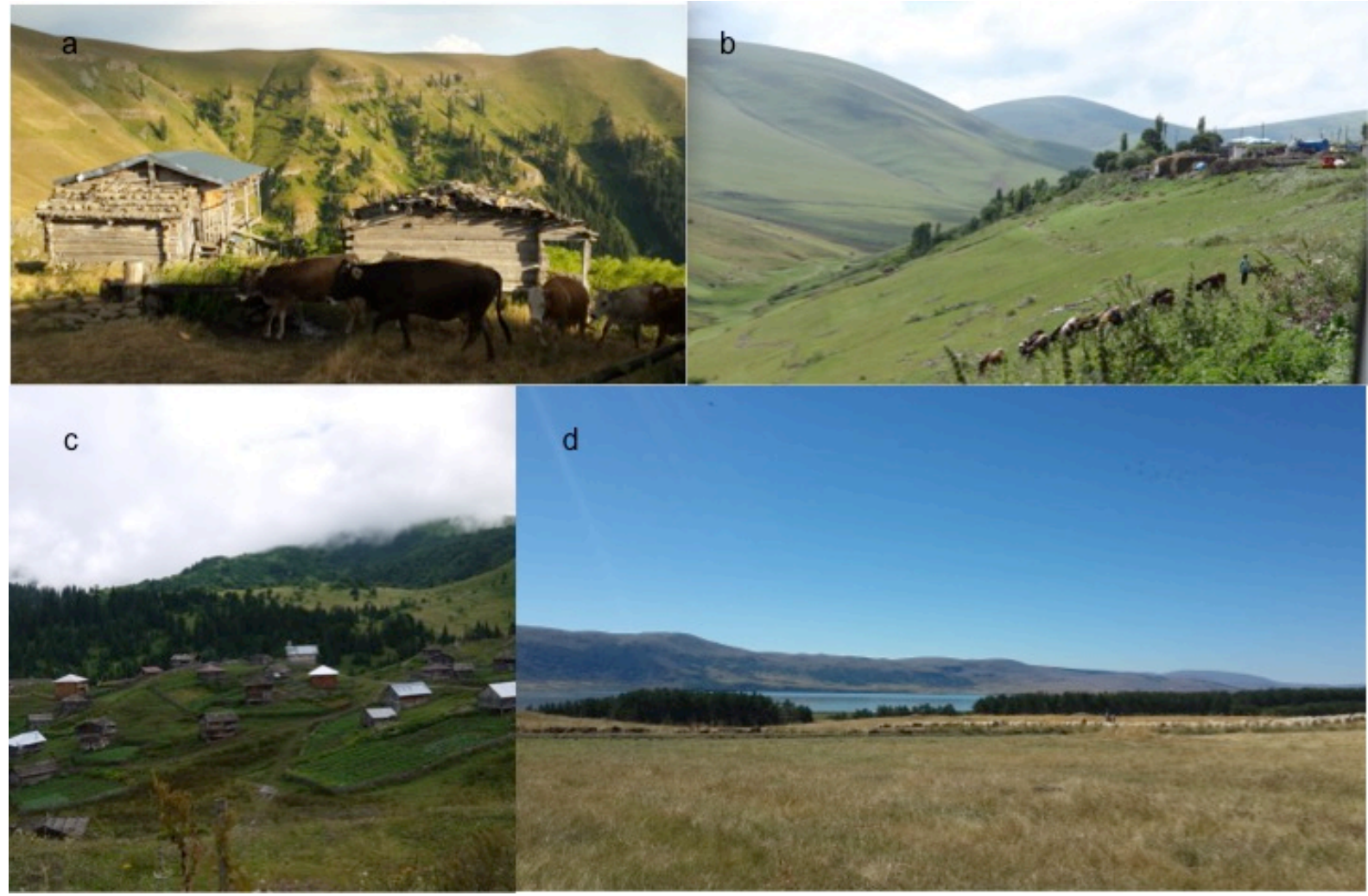

Figure 2. Landscapes a) Artvin, highland houses and livestock in subalpine b) Ardahan, cattle and geese graze together in highland meadows c) Adjara, highland houses usually settled nearby forest edge d) SamstkheJavakheti, sheep flock nearby Kartsakhi lake.

\section{Taxonomic Identification of plants}

Preliminary identification of plant species was carried out in the field by the authors. The plants were photographed together with their coordinates and then herbarium specimens were prepared by the first author for further identification. Relevant flora resources were used for identification (Davis 19651985; Davis et al. 1988; Güner et al. 2000; Ketskhoveli et al. 1971-2011; Komarov 1968-2002). Some of the species were identified through detailed plant and habitat descriptions and previously recorded folk names. Identified specimens from Georgia were stored in the National Herbarium of Georgia, specimens identified in Turkey were stored in the Herbarium of Artvin Çoruh University. Species were named based on current accepted names from the Plant List (2013). Furthermore, plant synonyms were given after Güner et al. (2012) and Gagnidze (2005).

\section{Data analysis}

All reported plant species and their relevant ethnobotanical data were entered into a Microsoft Excel spread sheet in a use-report (UR) based order. Each different use in every use-category counted as one UR. In this paper, ethnobotanical data of only wild (non-cultivated) plants used as ethnoveterinary, and fodder purposes as well as plants used against evil eye for animal health care from 2017 and 2018 fieldwork were considered in the analysis. Ethnoveterinary uses include wild plants used for the treatment of gastrointestinal, dermatological, parasitic, reproductive, respiratory, musculoskeletal, and poisoning. Two indices were used to compare the relative importance of species in each country.

a) The Cultural Importance index (Cl) (Pardo-deSantayana et al. 2007).

$$
C I=\sum_{i=1}^{i=N U} \frac{U R i}{N}
$$

NU: Total number of uses; i: varies from one use to $\mathrm{NU}$; $\mathrm{N}$ : number of participants in the survey; UR: Use report.

b) Relative frequency of citation (RFC) (Tardío \& Pardo-de-Santayana 2008): RFC $=$ FC/N

FC (frequency of citation) $=$ number of informants who mention the use of the species; $\mathrm{N}=$ number of participants in the survey. 


\section{Results and Discussion}

In total, 113 citations (51 Georgia, 62 Turkey) of 38 wild plant species (27 Georgia, 21 Turkey) for ethnoveterinary purposes, and 186 citations of 61 wild plant species (38 Georgia, 46 Turkey) as fodder were obtained in the study area. 35 citations of 12 species (4 Georgia, 11 Turkey) were also used to protect animals against evil eye. Among recorded 88 species, 10 species in ethnoveterinary use, 23 species as fodder and 3 species used against evil eye, were common in both countries. Table 1 summarizes the information about the usage of the 88 wild plant species. Comparing 136 species-use combinations of these species, participants in both countries share similar knowledge of 34 use incidences for 28 wild plant species in common. Most important of these species are Veratrum album, Trifolium spp., Viburnum lantana, Malus montana, Achillea millefolium, Sorbus aucuparia, Picea orientalis, Ruscus colchicus, Sambucus ebulus and Viscum album. Table 1 also shows the similarities and differences between information reported in this study and reports from 14 literature sources mainly from Turkish Caucasus and South Caucasus as well as with a comprehensive review about ethnoveterinary medicine from Turkey. Of this study's 88 wild plant species and 136 species-use combinations, 50 of the plant species and only 30 of the recipes are similar to those in the mentioned literature reports. The most frequently cited species in the literature consistent with this study's reports are: Veratrum album, Helleborus orientalis, Viscum album, Quercus petrea sp. iberica, Sambucus ebulus, Berberis vulgaris and Artemisia absinthium. Common species would be indicative of consensus and high cultural value for the ethnoveterinary knowledge of certain wild plant species in the Caucasus. Moreoever there are several species which have not been reported in the mentioned literature namely, Atriplex hortensis, Achillea millefolium, Eryngium giganteum, Senecio sp., Tanacetum sp., Betula litwinowii, Sedum sp., Dryopteris filix-mas, Gentiana sp., Origanum vulgare, Picea orientalis, Polygonum bistorta, Sibbaldia parviflora and Sorbus aucuparia.

For ethnoveterinary medicine, most frequently used families in Georgia are Asteraceae (8 species) and Melanthiaceae (1), whereas in Turkey they are Melanthiaceae (1 species), Rosaceae (3), and Pinaceae (1). In Georgia, the most important species are Veratrum album and Achillea millefolium, while in Turkey they are Veratrum album and Picea orientalis (Fig. 3).

Among these species, Veratrum album was reported throughout the study area in each administrative region with similar usage in both countries. However, in the literature it has been reported only in Georgia (Bussmann et al. 2016a, 2016b, 2017, 2018, 2020a, 2020b). On the other hand, Achillea millefolium and Picea orientalis were mainly mentioned in SamtskheJavakheti and in Artvin respectively. Interestingly, Achillea and Picea have not been reported in the compared literature before. More work is needed for detailed evaluation of ethnoveterinary use of these species in Turkey, Georgia and the Caucasus.

Regarding the plant parts used for ethnoveterinary, aerial part (mainly with flowers) with $45 \%$ of the UR were the most frequently used part in Georgia. It is followed by root $(24 \%)$ and entire plant $(10 \%)$. However, root with $42 \%$ of the UR is mostly preferred in Turkey, followed by aerial part (34\%) and resin (11\%) (Table 2). Most of the root usage originates from Veratrum album to cure parasitic diseases in both countries. On the other hand, aerial part with flowers has an important role in gastrointestinal disorders in Georgia. Among the preparation methods, the most common preparation in both countries were decoction of plant in water/milk (53\% of UR in Georgia, $48 \%$ in Turkey). It was followed by water infusion of the plants (22\% of the UR) in Georgia, whereas poultice or plaster $(26 \%)$ in Turkey. The remedies were applied mainly internally in Georgia ( $76 \%$ of UR), whereas externally $(71 \%)$ in Turkey (Table 2).

The most cited plant species used for ethnoveterinary, fodder and against evil eye were presented in Table 3. Wild plants have important roles especially for gastrointestinal disease $(53 \%$ UR) in Georgia, while dermatological (35\% UR) and parasitic diseases (34\%) were the most commonly mentioned problems in Turkey (Fig. 4). Almost all the plant species were mentioned to treat ailments of cattle (37 species), while 4 species were mentioned for calf, 3 species for chicken, 2 for sheep.

The most common gastrointestinal complaints and their treatments differ in both countries. In Georgia, giving a water infusion of Achillea millefolium aerial parts with flowers to cattle is a cure for stomachache and diarrhea, whereas in Turkey giving a water infusion of Verbascum sp. aerial part or a water decoction of Sorbus aucuparia young branches with leaves are used as wormer. The use of Verbascum with same purpose and application was also reported in Turkey (Altundağ 2009, Erarslan \& Kültür 2019). 
Table 1. Wild plants mentioned for ethnoveterinary and fodder use in the Western Lesser Caucasus.

\begin{tabular}{|c|c|c|c|c|c|c|c|c|c|}
\hline \multirow{2}{*}{$\begin{array}{l}\text { Latin names of families and } \\
\text { species (collector or digital } \\
\text { photograph number) }^{a}\end{array}$} & \multirow{2}{*}{$\begin{array}{l}\text { Recorded local } \\
\text { names }^{b}\end{array}$} & \multirow{2}{*}{$\begin{array}{l}\text { Recorded plant } \\
\text { part/s, preparation } \\
\text { and administrationc }\end{array}$} & \multirow[t]{2}{*}{ Use categories $^{d}$} & \multirow{2}{*}{$\begin{array}{l}\text { Domestic } \\
\text { animals }\end{array}$} & \multicolumn{2}{|c|}{$\mathrm{Cle}^{\mathrm{e}}$} & \multicolumn{2}{|c|}{ RFC $^{f}$} & \multirow[t]{2}{*}{ Use in the literatureg } \\
\hline & & & & & $\begin{array}{l}\text { Geo } \\
n=45\end{array}$ & $\begin{array}{l}\text { Tur } \\
n=74\end{array}$ & $\begin{array}{l}\text { Geo } \\
n=45\end{array}$ & $\underset{n=74}{\text { Tur }}$ & \\
\hline \multicolumn{10}{|l|}{ ADOXACEAE } \\
\hline $\begin{array}{l}\text { Sambucus ebulus L. } \\
\text { (FP-SO 19) } \\
\text { (CK, SO 1452, 1502) }\end{array}$ & $\begin{array}{l}\text { antsli (Geo), buzyna } \\
\text { (Rus), antsli, inchiri } \\
\text { (Laz) }\end{array}$ & $\begin{array}{l}1 \text { aerial parts } \\
2 \text { roots, in fodder } \\
3 \text { roots, infusion in } \\
\text { water, externally }\end{array}$ & \begin{tabular}{|l|} 
fodder 1 \\
antidote 2 \\
stomachache 3
\end{tabular} & cattle & 0,07 & 0,08 & 0,07 & 0,08 & $\begin{array}{l}\text { 2, 9, } 15 \text { (gastrointestinal, } \\
\text { respiratory, dermal, } \\
\text { wound, inflammatory } \\
\text { swelling, analgesic, } \\
\text { mastitis, ticks, chick } \\
\text { disease, acaricide) } \\
\end{array}$ \\
\hline $\begin{array}{l}\text { Sambucus nigra L. } \\
\text { (CK, SO 798) }\end{array}$ & \begin{tabular}{|l|} 
didgula, dudgula \\
(Geo), denderejik (Kur), \\
antsli, düldül ağacı \\
\end{tabular} & $\begin{array}{l}1 \text { young branches } \\
\text { with } \\
\text { leaves }\end{array}$ & fodder 1 & cattle & - & 0,01 & - & 0,01 & $\begin{array}{l}15 \text { (antifungal, } \\
\text { antiparasitic, wound) }\end{array}$ \\
\hline $\begin{array}{l}\text { Viburnum lantana L. } \\
\text { (CK, SO 455) } \\
(\text { CK, SO 1498, 1664, 1673, } \\
1704)\end{array}$ & $\begin{array}{l}\text { uzani, uzni (Geo), } \\
\text { germeşe (Tur), } \\
\text { garnavaşi, uzan, uzani, } \\
\text { germoşe, germeşe }\end{array}$ & $\begin{array}{l}\text { branches, hang on } \\
\text { animals' forehead or } \\
\text { tail, touch animal } \\
\text { with stick of it } \\
2 \text { young branches } \\
\text { with leaves, } \\
\text { decoction in water, } \\
\text { internally, small } \\
\text { amount } \\
3 \text { young branches } \\
\text { with leaves } \\
\end{array}$ & $\begin{array}{l}\text { belief (evil eye) } 1 \\
\text { diarrhea } 2 \\
\text { fodder } 3\end{array}$ & cattle & 0,11 & 0,09 & 0,07 & 0,09 & 5 \\
\hline $\begin{array}{l}\text { Viburnum orientale Pall. } \\
\text { (CK, SO 104, } 532\end{array}$ & gelbaraca,zakule & $\begin{array}{l}1 \text { young branches } \\
\text { with } \\
\text { leaves }\end{array}$ & fodder 1 & cattle & 0,02 & - & 0,02 & - & \\
\hline \multicolumn{10}{|l|}{ AMARANTHACEAE } \\
\hline $\begin{array}{l}\text { Atriplex hortensis L. } \\
\text { (CK, SO 1535) }\end{array}$ & $\begin{array}{l}\text { reş pancar (Kur), siyah } \\
\text { pancar, unuca (Tur) }\end{array}$ & $\begin{array}{l}1 \text { aerial parts, } \\
\text { decoction } \\
\text { in milk, poultice } \\
\end{array}$ & inflammation 1 & cattle & - & 0,01 & - & 0,01 & 5 (fodder) \\
\hline \multicolumn{10}{|l|}{ APIACEAE } \\
\hline $\begin{array}{l}\text { Chaerophyllum sp. } \\
\text { (CK, SO 509) }\end{array}$ & $\begin{array}{l}\text { buten (Rus), ghimi, } \\
\text { gimi (Geo), mendek, } \\
\text { mendik, harhanduk } \\
\text { (Arm),kımı, kımi, atol } \\
\text { (Tur) }\end{array}$ & 1 aerial parts & fodder 1 & pig & 0,02 & - & 0,02 & - & 14 \\
\hline
\end{tabular}




\begin{tabular}{|c|c|c|c|c|c|c|c|c|c|}
\hline $\begin{array}{l}\text { Heracleum spp. } \\
\text { (CK, SO 470) } \\
\text { (CK, SO 1338) }\end{array}$ & $\begin{array}{l}\text { dilkha, dilgha, } \\
\text { telaharshi (Geo), kekre, } \\
\text { kekro (Tur-Kur), dilka, } \\
\text { telehaş, datibaba, } \\
\text { kokulu pototo, kekro }\end{array}$ & \begin{tabular}{|l}
1 aerial parts \\
2 aerial parts, mix \\
with Petasites boil in \\
water, internally
\end{tabular} & $\begin{array}{l}\text { fodder } \mathbf{1 , 2} \\
\text { increase milk } \\
\text { production } \mathbf{1}\end{array}$ & cattle & 0,07 & 0,07 & 0,07 & 0,07 & $\begin{array}{l}2 \text { (mastitis), } \\
10,15\end{array}$ \\
\hline \multicolumn{10}{|l|}{ AQUIFOLIACEAE } \\
\hline $\begin{array}{l}\text { llex colchica Pojark. } \\
\text { (CK, SO 74, 86) }\end{array}$ & badzgari (Geo) & 1 aerial parts & fodder 1 & goat & 0,02 & - & 0,02 & - & 2 \\
\hline \multicolumn{10}{|l|}{ ARALIACEAE } \\
\hline $\begin{array}{l}\text { Hedera colchica (K.Koch) } \\
\text { K.Koch } \\
\text { CK, SO 84) } \\
\text { (FP-SO 12) }\end{array}$ & $\begin{array}{l}\text { suro (Geo), suro (Geo), } \\
\text { sici (Laz) }\end{array}$ & 1 aerial parts & fodder 1 & cattle & 0,02 & 0,04 & 0,02 & 0,04 & 2,9 \\
\hline \multicolumn{10}{|l|}{ ASPARAGACEAE } \\
\hline $\begin{array}{l}\text { Ruscus colchicus Yeo } \\
\text { (CK, SO 807) }\end{array}$ & $\begin{array}{l}\text { dzmerkhli } \\
\text { (Geo),zımerkli, } \\
\text { zermek, zermak, } \\
\text { mercan otu (Tur), } \\
\text { paskar }\end{array}$ & 1 aerial parts & fodder 1 & cattle & 0,04 & 0,09 & 0,04 & 0,09 & 9 \\
\hline \multicolumn{10}{|l|}{ ASTERACEAE } \\
\hline $\begin{array}{l}\text { Achillea millefolium L. } \\
(\mathrm{CK}, \text { SO } 476,495,533) \\
(\mathrm{CK}, \mathrm{SO} 1341,1548)\end{array}$ & $\begin{array}{l}\text { hazerantertik (Arm), } \\
\text { melagunda (Geo), } \\
\text { besmertnik (Rus), } \\
\text { pharsmanduki (Geo), } \\
\text { tisiachelistnik } \\
\text { (Rus) hırpkesen, kılıç } \\
\text { otu, civanperçemi (Tur) }\end{array}$ & $\begin{array}{l}1 \text { aerial parts with } \\
\text { flowers, infusion in } \\
\text { water, internally } \\
2 \text { aerial parts with } \\
\text { flowers, decoction in } \\
\text { water, internally }\end{array}$ & $\begin{array}{l}\text { diarrhea 1,2 } \\
\text { stomachache 1, } 2 \\
\text { swollen stomach } 2 \\
\text { increase milk } \\
\text { production } 2\end{array}$ & $\begin{array}{c}\text { calf } \\
\text { chicken } \\
\text { cattle }\end{array}$ & 0,20 & 0,01 & 0,18 & 0,01 & \\
\hline $\begin{array}{l}\text { Anthemis sp. } \\
\text { (CK, SO 27) }\end{array}$ & $\begin{array}{l}\text { gvirila (Geo), } \\
\text { romashka (Rus), } \\
\text { papatya (Tur) }\end{array}$ & $\begin{array}{l}1 \text { flowers, decoction } \\
\text { in water, } \\
\text { externally }\end{array}$ & bath 1 & calf & 0,02 & - & 0,02 & - & 15 (diarrhea) \\
\hline $\begin{array}{l}\text { Arctium platylepis (Boiss \& } \\
\text { Balansa) Sosn ex Grossh. } \\
\text { (CK, SO 485) } \\
\text { (CK, SO 1387) }\end{array}$ & $\begin{array}{l}\text { dzirkvena, orovandi, } \\
\text { ghalaghunta } \\
\text { (Geo)ghabalak, } \\
\text { sherepuk, lopukh } \\
\text { (Rus), } \\
\text { düğe tabanı, kabalak } \\
\text { (Tur), dilhuna, hozik, } \\
\text { alahunda (Kur) }\end{array}$ & $\begin{array}{l}1 \text { leaves, poultice, } \\
\text { externally } \\
2 \text { aerial parts }\end{array}$ & $\begin{array}{l}\text { wound } 1 \\
\text { fodder } 2\end{array}$ & $\begin{array}{l}\text { cattle } \\
\text { rabbit }\end{array}$ & 0,02 & - & 0,02 & 0,01 & 14 (swelling of leg), 15 \\
\hline
\end{tabular}




\begin{tabular}{|c|c|c|c|c|c|c|c|c|c|}
\hline $\begin{array}{l}\text { Artemisia absinthium L. } \\
\text { (CK, SO 502) }\end{array}$ & $\begin{array}{l}\text { abzinda (Geo), ghelich } \\
\text { oti, polin (Rus), hevşan, } \\
\text { pire otu (Tur) }\end{array}$ & $\begin{array}{l}1 \text { aerial parts with } \\
\text { flowers, decoction in } \\
\text { water, internally }\end{array}$ & swollen stomach 1 & cattle & 0,02 & - & 0,02 & - & $\begin{array}{l}2 \text { (antibiotic), } \\
3,4 \text { (fever), } 5 \text { (wound), } 15 \\
\text { (parasitic disease, cold, } \\
\text { wound) }\end{array}$ \\
\hline $\begin{array}{l}\text { Cichorium intybus L. } \\
\text { (CK-SO 43) }\end{array}$ & $\begin{array}{l}\text { tsikoryi (Rus), } \\
\text { vardkachacha } \\
\text { (Geo), marçkakaç }\end{array}$ & $\begin{array}{l}1 \text { aerial parts, in } \\
\text { fodder }\end{array}$ & swollen stomach 1 & cattle & 0,02 & - & 0,02 & - & $\begin{array}{l}5 \text { (wound), 14, } \\
15 \text { (increasing milk } \\
\text { production) }\end{array}$ \\
\hline $\begin{array}{l}\text { Eryngium giganteum M Bieb } \\
\text { (CK, SO 486, 508) }\end{array}$ & $\begin{array}{l}\text { samkbila ekala (Geo), } \\
\text { push (Kur), nazar } \\
\text { dikeni, çakır dikeni } \\
\text { (Tur), kelem (Kur) }\end{array}$ & $\begin{array}{l}1 \text { aerial parts with } \\
\text { flowers, hang in barn } \\
2 \text { aerial parts with } \\
\text { flowers, decoction of } \\
1 \text { stem in } 2 \text { lt water, } \\
\text { internally }\end{array}$ & $\begin{array}{l}\text { belief (evil eye) } 1 \\
\text { diarrhea } 2\end{array}$ & cattle & 0,02 & 0,03 & 0,02 & 0,03 & \\
\hline $\begin{array}{l}\text { Petasites spp. } \\
\text { (FP-SO 41) }\end{array}$ & $\begin{array}{l}\text { bulgo, bulgho, } \\
\text { barambo (Geo), dilma } \\
\text { (Geo), burgvay, burgo } \\
\text { (Laz), davut yaprağı } \\
\text { (Tur) }\end{array}$ & $\begin{array}{l}1 \text { aerial parts } \\
2 \text { aerial parts, } \\
\text { decoction in water } \\
\text { mix in fodder }\end{array}$ & fodder 1,2 & cattle & 0,11 & 0,01 & 0,11 & 0,01 & $2,10,15$ (wound) \\
\hline $\begin{array}{l}\text { Senecio sp. } \\
\text { (FP-SO 42) }\end{array}$ & $\begin{array}{l}\text { khboshubla (Geo), } \\
\text { kharisshubla }\end{array}$ & $\begin{array}{l}1 \text { aerial parts with } \\
\text { flowers, } \\
\text { decoction in water, } \\
\text { externally }\end{array}$ & scabby 1 & cattle & 0,02 & - & 0,02 & - & \\
\hline $\begin{array}{l}\text { Tanacetum macrophyllum } \\
\text { (Waldst \& Kit.) Sch Bip. } \\
\text { syn: Pyrethrum macrophyllum } \\
\text { (Waldst \& Kit.) Willd. } \\
\text { (CK, SO 37) }\end{array}$ & $\begin{array}{l}\text { samthatha } \\
\text { (Geo), sandal otu, acı } \\
\text { papatya, (Tur) sendel }\end{array}$ & $\begin{array}{l}1 \text { aerial parts with } \\
\text { flowers, } \\
\text { infusion in water, } \\
\text { internally }\end{array}$ & indigestion 1 & cattle & 0,02 & - & 0,02 & - & \\
\hline $\begin{array}{l}\text { Taraxacum spp. } \\
\text { (CK, SO 69, 545) } \\
\text { (CK, SO 1289) }\end{array}$ & $\begin{array}{l}\text { babuatsvera (Geo), } \\
\text { khatutik (Arm), kaz otu, } \\
\text { sütlü ot, hindi yemi } \\
\text { (Tur) pızbizek (Kur) }\end{array}$ & 1 aerial parts, raw & fodder 1 & $\begin{array}{l}\text { rabbit } \\
\text { goose } \\
\text { chick } \\
\text { turkey }\end{array}$ & 0,02 & 0,07 & 0,02 & 0,05 & 14 (bloody diarrhea) \\
\hline $\begin{array}{l}\text { Tragopogon sp. } \\
\text { (CK, SO 494) } \\
\text { (FP-SO 15) }\end{array}$ & $\begin{array}{l}\text { phamphara (Geo), } \\
\text { sindz (Arm), yemlik } \\
\text { (Tur),pampara, yemlik, } \\
\text { sıpınk (Kur) }\end{array}$ & 1 aerial parts, raw & fodder 1 & goose & - & 0,01 & - & 0,01 & \\
\hline $\begin{array}{l}\text { Tussilago farfara L. } \\
\text { (FP-SO 45) } \\
\text { (FP-SO 46) }\end{array}$ & $\begin{array}{l}\text { viristerpa (Geo), } \\
\text { barambu, } \\
\text { porikuda,dilma (Geo), } \\
\text { biryüzlü yaprak (Tur) }\end{array}$ & $\begin{array}{l}1 \text { leaves } \\
2 \text { leaves, infusion in } \\
\text { water mix in fodder }\end{array}$ & $\begin{array}{l}\text { fodder } 1 \\
\text { increase milk } \\
\text { production } \mathbf{1}, 2\end{array}$ & cattle & 0,07 & 0,03 & 0,07 & 0,03 & 15 (inflammatory disease) \\
\hline
\end{tabular}




\begin{tabular}{|c|c|c|c|c|c|c|c|c|c|}
\hline \multicolumn{10}{|l|}{ BERBERIDACEAE } \\
\hline $\begin{array}{l}\text { Berberis vulgaris } \mathrm{L} . \\
\text { (CK, SO 458, 500) } \\
(\mathrm{CK}, \mathrm{SO} 56,1651,1693)\end{array}$ & $\begin{array}{l}\text { kotsakhuri (Geo), } \\
\text { barbaris (Rus), sarılık } \\
\text { ağacı karmuk (Tur), } \\
\text { koçahur }\end{array}$ & $\begin{array}{l}1 \text { branches with } \\
\text { leaves } \\
2 \text { branches with } \\
\text { leaves, decoction in } \\
\text { water, internally } \\
3 \text { branches, hang on } \\
\text { animals }\end{array}$ & $\begin{array}{l}\text { fodder } 1 \\
\text { antidote } 2 \\
\text { belief (evil eye) } 3\end{array}$ & cattle & 0,04 & 0,03 & 0,04 & 0,03 & $\begin{array}{l}5 \text { (anastaltic in injuries of } \\
\text { horses), } 8,15 \text { (jaundice), } \\
7 \text { (vascular stomatitis) }\end{array}$ \\
\hline \multicolumn{10}{|l|}{ BETULACEAE } \\
\hline $\begin{array}{l}\text { Betula litwinowii Doluch. } \\
\text { (CK, SO 22, 1590, 1695) }\end{array}$ & $\begin{array}{l}\text { arki (Geo), beryoza } \\
\text { (Rus), gechin } \\
\text { (Arm), kayın (Tur), arki }\end{array}$ & $\begin{array}{l}1 \text { inner barks, black } \\
\text { chewing gum, } \\
\text { plaster }\end{array}$ & wound 1 & cattle & - & 0,01 & - & 0,01 & \\
\hline $\begin{array}{l}\text { Carpinus betulus L. } \\
\text { (CK, SO 1044, 1488) }\end{array}$ & $\begin{array}{l}\text { tskhmela (Geo), gürgen } \\
\text { (Tur), tskhemla }\end{array}$ & $\begin{array}{l}1 \text { branches with } \\
\text { leaves }\end{array}$ & fodder 1 & cattle & - & 0,01 & - & 0,01 & \\
\hline \multicolumn{10}{|l|}{ BORAGINACEAE } \\
\hline $\begin{array}{l}\text { Symphytum spp. } \\
\text { (CK, SO 474) }\end{array}$ & $\begin{array}{l}\text { saro (Geo), okopnik } \\
\text { (Rus),mıtskapa, gelin } \\
\text { otu (Tur), su dodopali }\end{array}$ & 1 aerial parts & fodder 1 & cattle & 0,02 & 0,04 & 0,02 & 0,04 & \\
\hline \multicolumn{10}{|l|}{ BRASSICACEAE } \\
\hline $\begin{array}{l}\text { Capsella bursa-pastoris (L.) } \\
\text { Medik. } \\
\text { (CK, SO 538) } \\
\text { (CK, SO 289) }\end{array}$ & $\begin{array}{l}\text { mtskemsis chanta } \\
\text { (Geo), pastushya } \\
\text { sumka (Rus), acı gıcı, } \\
\text { kaz otu, çoban } \\
\text { dürmeği, ördek otu, } \\
\text { civciv otu }\end{array}$ & 1 aerial parts & fodder 1 & goose & - & 0,08 & - & 0,08 & \\
\hline $\begin{array}{l}\text { Cardamine sp. } \\
\text { (FP-SO 20, 21, 22) }\end{array}$ & $\begin{array}{l}\text { tere (Tur), tita, acıgıcı, } \\
\text { kıçi, sukupiyi (Laz), } \\
\text { gedim (Arm) }\end{array}$ & 1 aerial parts & fodder 1 & goose & - & 0,01 & - & 0,01 & \\
\hline \multicolumn{10}{|l|}{ BUXACEAE } \\
\hline Buxus sempervirens L. & bza (Geo),şimşir (Tur) & $\begin{array}{l}1 \text { branches, hang on } \\
\text { animals' forehead }\end{array}$ & belief (evil eye) 1 & cattle & - & 0,01 & - & 0,01 & \\
\hline \multicolumn{10}{|l|}{ CONVOLVULACEAE } \\
\hline $\begin{array}{l}\text { Convolvulus arvensis L. } \\
(\mathrm{CK}, \mathrm{SO} 30)\end{array}$ & $\begin{array}{l}\text { khviara (Geo), patatuk } \\
\text { (Arm), tıshapa, } \\
\text { sarmaşık (Tur) }\end{array}$ & 1 aerial parts & fodder 1 & $\begin{array}{l}\text { rabbit } \\
\text { cattle }\end{array}$ & 0,02 & 0,03 & 0,02 & 0,03 & 15 (wound) \\
\hline
\end{tabular}




\begin{tabular}{|c|c|c|c|c|c|c|c|c|c|}
\hline CRASSULACEAE & & & & & & & & & \\
\hline $\begin{array}{l}\text { Sedum sp. } \\
\text { (FP-SO 52) }\end{array}$ & \begin{tabular}{|l} 
tknikura (Geo), \\
kldisvashla (Geo), \\
saknatura (Geo), \\
mamur (Arm), ukdavra, \\
katakuta, camış kulağı \\
(Tur), hatun parmağı, \\
kaya elması, at dişi \\
(Tur), tknikura
\end{tabular} & \begin{tabular}{|l}
1 aerial parts \\
2 aerial parts, \\
poultice \\
3 aerial parts, raw
\end{tabular} & \begin{tabular}{|l|} 
fodder 1 \\
wound 2 \\
internal worms 3
\end{tabular} & $\begin{array}{c}\text { chicken } \\
\text { cattle }\end{array}$ & - & 0,05 & - & 0,03 & \\
\hline \multicolumn{10}{|l|}{ DIPSACACEAE } \\
\hline $\begin{array}{l}\text { Cephalaria gigantea (Ledeb.) } \\
\text { Bobrov } \\
\text { (CK, SO 1015,1494) }\end{array}$ & $\begin{array}{l}\text { polio (Geo),kanteper } \\
\text { (Tur), poliyo }\end{array}$ & 1 aerial parts & fodder 1 & cattle & 0,02 & - & 0,02 & - & 14 \\
\hline \multicolumn{10}{|l|}{ DRYOPTERIDACEAE } \\
\hline $\begin{array}{l}\text { Dryopteris filix-mas (L.) Schott } \\
\text { (CK, SO 1346) }\end{array}$ & $\begin{array}{l}\text { etseri (Geo), blentso } \\
\text { (Laz), gvimra } \\
\text { (Geo),imkhri, etseri } \\
\text { (Geo) } \\
\end{array}$ & $\begin{array}{l}1 \text { entire plant, dried } \\
2 \text { roots, internally }\end{array}$ & $\begin{array}{l}\text { fodder } 1 \\
\text { indigestion } 2\end{array}$ & cattle & 0,09 & 0,01 & 0,09 & 0,01 & 10 \\
\hline \multicolumn{10}{|l|}{ EQUISETACEAE } \\
\hline $\begin{array}{l}\text { Equisetum arvense L. } \\
\text { (FP-SO 56) }\end{array}$ & \begin{tabular}{|l} 
datvipanchari, \\
nadzvabalakha (Geo), \\
shvita,datvisepeta, \\
kolabešk, kırkkilit otu, \\
atkuyruğu (Tur) \\
\end{tabular} & 1 aerial parts & fodder 1 & cattle & - & 0,04 & - & 0,04 & 15 (bloody urination) \\
\hline \multicolumn{10}{|l|}{ FABACEAE } \\
\hline $\begin{array}{l}\text { Astracantha microcephala } \\
\text { (Willd.) Podlech } \\
\text { syn: Astragalus microcephalus } \\
\text { Willd. } \\
\text { CK, SO 1583, 1713) }\end{array}$ & geven (Tur) & $\begin{array}{l}1 \text { roots, plaster, } \\
\text { externally } \\
2 \text { roots, mix with hay } \\
\text { in ploughing time } \\
\text { (karakotan) } \\
3 \text { roots, decoction in } \\
\text { water, internally } \\
4 \text { branches, hang on } \\
\text { animals' forehead }\end{array}$ & $\begin{array}{l}\text { wound } 1 \\
\text { fodder } 2 \\
\text { foot-and-mouth } \\
\text { disease } 3 \\
\text { belief (evil eye) } 4 \\
\end{array}$ & cattle & - & 0,09 & - & 0,09 & 6,7 (blacklegs) \\
\hline $\begin{array}{l}\text { Trifolium alpestre L. } \\
\text { (FP-SO 58) } \\
\text { (FP-SO 59) }\end{array}$ & \begin{tabular}{|l} 
samkura, tsteli \\
samkura (Geo), yonca \\
(Tur), klever (Rus), üç \\
kulak otu (Tur), \\
samkuri
\end{tabular} & 1 aerial parts & fodder $\mathbf{1}$ & cattle & 0,02 & 0,01 & 0,02 & 0,01 & \\
\hline
\end{tabular}




\begin{tabular}{|c|c|c|c|c|c|c|c|c|c|}
\hline $\begin{array}{l}\text { Trifolium ambiguum M.Bieb. } \\
\text { (FP-SO 60) }\end{array}$ & $\begin{array}{l}\text { yonca, klever (Rus), } \\
\text { yereknuk (Arm),tut otu, } \\
\text { üç kulak (Tur) }\end{array}$ & 1 aerial parts & fodder 1 & cattle & 0,02 & 0,01 & 0,02 & 0,01 & \\
\hline $\begin{array}{l}\text { Trifolium canescens Willd. } \\
\text { (FP-SO 61) }\end{array}$ & $\begin{array}{l}\text { tut, } \\
\text { üç kulak otu, yonca } \\
\text { (Tur), }\end{array}$ & 1 aerial parts & fodder 1 & cattle & - & 0,03 & - & 0,03 & \\
\hline $\begin{array}{l}\text { Trifolium pratense } \mathrm{L} . \\
\text { (FP-SO 63) }\end{array}$ & $\begin{array}{l}\text { samkura (Geo), } \\
\text { yereknuk (Arm), üç } \\
\text { kulak, yonca (Tur), üç } \\
\text { kulak, samkura (Geo), } \\
\text { yonca, elma otu } \\
\end{array}$ & 1 aerial parts & fodder 1 & cattle & - & 0,03 & - & 0,03 & $\begin{array}{l}10,14 \text { (increase milk } \\
\text { secretion) }\end{array}$ \\
\hline Trifolium sp. & $\begin{array}{l}\text { samkura (Geo), klever } \\
\text { (Rus), yereknuk (Arm), } \\
\text { yonca (Tur),yonca, } \\
\text { samkura (Geo), üç } \\
\text { kulak, kır yoncası, } \\
\text { samkuri, üç yaprak }\end{array}$ & $\begin{array}{l}1 \text { aerial parts } \\
2 \text { aerial parts, mix } \\
\text { with Urtica, Rumex, } \\
\text { Anthemis, flour and } \\
\text { cream, poultice, } \\
\text { externally } \\
\end{array}$ & $\begin{array}{l}\text { fodder } 1 \\
\text { increase milk } \\
\text { production } 1 \\
\text { fracture } 2 \\
\text { wound } 2\end{array}$ & $\begin{array}{l}\text { calf } \\
\text { cattle }\end{array}$ & 0,18 & 0,18 & 0,18 & 0,18 & $\begin{array}{l}3,9,12,15 \text { (swelling, } \\
\text { difficulty of birth, } \\
\text { retained plecenta, } \\
\text { increasing milk secretion) }\end{array}$ \\
\hline $\begin{array}{l}\text { Vicia villosa Roth } \\
\text { (FP-SO 64) }\end{array}$ & $\begin{array}{l}\text { harci, koranga, } \\
\text { gıvartlay, yonca otu, } \\
\text { külül, gül kürülü (Tur) }\end{array}$ & $\begin{array}{l}1 \text { aerial parts with } \\
\text { flowers }\end{array}$ & fodder 1 & cattle & - & 0,07 & - & 0,07 & $\begin{array}{l}\text { (increasing milk } \\
\text { secretion), 10, 11, 14, } 15 \\
\text { (gastrointestinal disease, } \\
\text { dermal disease, wound, } \\
\text { parasitic disease, } \\
\text { increasing milk secretion, } \\
\text { swelling, vitamin } \\
\text { deficiency, difficulty of } \\
\text { birth, retained placenta, } \\
\text { appetizer) }\end{array}$ \\
\hline \multicolumn{10}{|l|}{ FAGACEAE } \\
\hline $\begin{array}{l}\text { Fagus orientalis Lipsky. } \\
\text { (CK, SO 1434) }\end{array}$ & $\begin{array}{l}\text { tsipeli (Geo), tsipela } \\
\text { (Geo) }\end{array}$ & $\begin{array}{l}1 \text { young branches } \\
\text { and leaves }\end{array}$ & fodder 1 & cattle & - & 0,01 & - & 0,01 & 5,11 \\
\hline $\begin{array}{l}\text { Quercus macranthera } \\
\text { Fisch \& C.A.Mey ex Hohen. } \\
\text { (CK, SO 1796) }\end{array}$ & $\begin{array}{l}\text { mukha (Geo), pelut, } \\
\text { dub (Arm),palut ağacı } \\
\text { (Tur) }\end{array}$ & 1 acorns, raw & fodder 1 & sheep & - & 0,01 & - & 0,01 & \\
\hline $\begin{array}{l}\text { Quercus petraea subsp iberica } \\
\text { (Steven ex M.Bieb.) Krassiln } \\
\text { syn: Quercus iberica Steven ex } \\
\text { M.Bieb. } \\
\text { (CK, SO 126, 259) } \\
\text { (CK, SO 785, 1046, 1049, } \\
\text { 1057, 1487) }\end{array}$ & $\begin{array}{l}\text { mukha (Geo), dub } \\
\text { (Arm) ghoris tsabli } \\
\text { (Geo), pelit, pelut, } \\
\text { palut, meşe (Tur), ko } \\
\text { (Arm) }\end{array}$ & $\begin{array}{l}1 \text { acorns, raw } \\
2 \text { outer bark, } \\
\text { decoction in water } \\
3 \text { young branches } \\
\text { with leaves }\end{array}$ & \begin{tabular}{|l} 
fodder 1,3 \\
stomachache 2
\end{tabular} & $\begin{array}{c}\text { pig } \\
\text { cattle } \\
\text { sheep }\end{array}$ & 0,07 & 0,05 & 0,07 & 0,05 & $\begin{array}{l}\text { 3, } 5 \text { (diarrhea, } \\
\text { toothache) }\end{array}$ \\
\hline
\end{tabular}




\begin{tabular}{|c|c|c|c|c|c|c|c|c|c|}
\hline $\begin{array}{l}\text { Quercus pontica K.Koch } \\
\text { (CK, SO 72) }\end{array}$ & tkis mukha (Geo) & 1 acorns, raw & fodder 1 & pig & 0,02 & - & 0,02 & - & \\
\hline \multicolumn{10}{|l|}{ GENTIANACEAE } \\
\hline $\begin{array}{l}\text { Gentiana asclepiadea L. } \\
\text { (CK, SO 64, 93, 530) } \\
\text { (FP-SO 65) }\end{array}$ & $\begin{array}{l}\text { asistava (Geo), } \\
\text { mayasir otu (Tur), } \\
\text { asistava }\end{array}$ & $\begin{array}{l}1 \text { aerial parts with } \\
\text { flowers, raw } \\
2 \text { aerial parts with } \\
\text { flowers, infusion in } \\
\text { water, internally } \\
\end{array}$ & $\begin{array}{l}\text { stomachache } 1 \\
\text { diarrhea } 2\end{array}$ & cattle & 0,02 & 0,01 & 0,02 & 0,01 & \\
\hline \multicolumn{10}{|l|}{ HYPERICACEAE } \\
\hline $\begin{array}{l}\text { Hypericum bupleuroides } \\
\text { Griseb. } \\
\text { (CK, SO 47) }\end{array}$ & tiknikuda & 1 entire plant & fodder 1 & lamb & 0,02 & - & 0,02 & - & \\
\hline $\begin{array}{l}\text { Hypericum perforatum L. } \\
\text { (CK, SO 475) } \\
\text { (CK, SO 1480) }\end{array}$ & $\begin{array}{l}\text { krazana (Geo), } \\
\text { zveroboy (Rus),sarı } \\
\text { çiçek, kaymak çiçeği, } \\
\text { sarı kanataron, } \\
\text { mayasıl otu (Tur) } \\
\end{array}$ & $\begin{array}{l}1 \text { aerial parts with } \\
\text { flowers, dried and } \\
\text { powdered, poultice }\end{array}$ & wound 1 & cattle & - & 0,01 & - & 0,01 & $\begin{array}{l}15 \text { (gastrointestinal, } \\
\text { respiratory, dermal } \\
\text { disease, mastitis) }\end{array}$ \\
\hline \multicolumn{10}{|l|}{ JUNCACEAE } \\
\hline $\begin{array}{l}\text { Juncus sp. } \\
\text { (CK, SO 34, 65) }\end{array}$ & $\begin{array}{l}\text { dzrokhis balakhi (Geo), } \\
\text { tchilophi (Geo),cil } \\
\text { (Tur), çilopay }\end{array}$ & 1 aerial parts & fodder 1 & cattle & 0,02 & - & 0,02 & - & \\
\hline \multicolumn{10}{|l|}{ LAMIACEAE } \\
\hline $\begin{array}{l}\text { Mentha longifolia (L.) L. } \\
\text { (CK, SO 683) }\end{array}$ & $\begin{array}{l}\text { tentso (Geo), veluri } \\
\text { pitna (Geo), pitna } \\
\text { (Geo), daghdz (Arm), } \\
\text { nana, gareuli pitna } \\
\text { (Geo), yarpuz (Tur), } \\
\text { tentso, pitna (Geo), } \\
\text { yabani nane, nane } \\
\text { (Tur), punk (Kur) }\end{array}$ & $\begin{array}{l}1 \text { aerial parts with } \\
\text { flowers, } \\
\text { decoction in water, } \\
\text { externally }\end{array}$ & $\begin{array}{l}\text { foot-and-mouth } \\
\text { disease } 1 \\
\text { wound } 1\end{array}$ & cattle & - & 0,03 & - & 0,03 & $\begin{array}{l}15 \text { (parasitic, reproductive, } \\
\text { respiratory disease, } \\
\text { diarrhea) }\end{array}$ \\
\hline $\begin{array}{l}\text { Origanum vulgare L. } \\
\text { (CK,SO 478) } \\
\text { (CK,SO 1283) }\end{array}$ & $\begin{array}{l}\text { tavshava (Geo), } \\
\text { dushitza (Rus), } \\
\text { marmichi (Geo), urtz } \\
\text { (Arm), çay otu, çam } \\
\text { çayı, kekik (Tur) }\end{array}$ & $\begin{array}{l}1 \text { aerial parts with } \\
\text { flowers, infusion in } \\
\text { water, internally } \\
2 \text { aerial parts with } \\
\text { flowers, in fodder }\end{array}$ & $\begin{array}{l}\text { diarrhea } 1 \\
\text { stomachache } 2 \\
\text { fodder } 2\end{array}$ & cattle & 0,04 & 0,01 & 0,04 & 0,01 & \\
\hline $\begin{array}{l}\text { Salvia glutinosa L } \\
\text { (CK, SO } 51,95)\end{array}$ & $\begin{array}{l}\text { purchumela } \\
\text { (Laz), adaçayı, } \\
\text { purçumela (Laz), } \\
\text { purşukuna }\end{array}$ & 1 young aerial parts & fodder 1 & cattle & 0,02 & - & 0,02 & - & \\
\hline
\end{tabular}




\begin{tabular}{|c|c|c|c|c|c|c|c|c|c|}
\hline \multicolumn{10}{|l|}{ MELANTHIACEAE } \\
\hline $\begin{array}{l}\text { Veratrum album L. } \\
\text { CK, SO 52) } \\
\text { (CK, SO 1546) }\end{array}$ & $\begin{array}{l}\text { shkhama (Geo), } \\
\text { shkhami, aputaraki } \\
\text { (Geo),şıkhami, } \\
\text { abitarat, abutarat } \\
\text { (Geo), çoplama, } \\
\text { şamay, avu, } \\
\text { camışkıran (Tur) }\end{array}$ & $\begin{array}{l}1 \text { aerial parts, dried } \\
2 \text { roots, decoction in } \\
\text { water, bath, } \\
\text { externally } \\
3 \text { entire plant, } \\
\text { decoction in water, } \\
\text { bath } \\
4 \text { roots, decoction in } \\
\text { water, internally }\end{array}$ & \begin{tabular}{|l|} 
fodder $\mathbf{1}$ \\
scabby $\mathbf{2}$ \\
wound $\mathbf{2}$ \\
lice $\mathbf{2}$ \\
mastitis 2 \\
stomachache 4 \\
internal worms 4 \\
indigestion 4 \\
constipation 4
\end{tabular} & $\begin{array}{l}\text { sheep } \\
\text { cattle }\end{array}$ & 0,27 & 0,34 & 0,27 & 0,34 & $2,3,4,9,12$ \\
\hline \multicolumn{10}{|l|}{ OLEACEAE } \\
\hline $\begin{array}{l}\text { Fraxinus angustifolia subsp } \\
\text { oxycarpa (Willd.) Franco \& } \\
\text { Rocha Afonso } \\
\text { (CK, SO 1482) }\end{array}$ & $\begin{array}{l}\text { ipni (Geo), dişbudak } \\
\text { (Tur), ipni (Geo) }\end{array}$ & $\begin{array}{l}1 \text { young branches } \\
\text { and leaves }\end{array}$ & fodder 1 & cattle & - & 0,01 & - & 0,01 & 15 (chicken disease) \\
\hline \multicolumn{10}{|l|}{ PAPAVERACEAE } \\
\hline $\begin{array}{l}\text { Chelidonium majus L. } \\
\text { (FP-SO 70) }\end{array}$ & khristesiskhla (Geo) & $\begin{array}{l}1 \text { aerial parts, } \\
\text { poultice }\end{array}$ & stop bleeding 1 & cattle & 0,02 & - & 0,02 & - & 9, 15 (liver disease) \\
\hline \multicolumn{10}{|l|}{ PINACEAE } \\
\hline $\begin{array}{l}\text { Picea orientalis (L.) Peterm. } \\
\text { (CK, SO 110, 446) } \\
\text { (CK, SO 658, 1041, 1676) }\end{array}$ & $\begin{array}{l}\text { nadzvi (Geo), yolka } \\
\text { (Rus), ladin (Tur), } \\
\text { nadzvi (Geo) }\end{array}$ & $\begin{array}{l}1 \text { resin, mix resin } \\
\text { with butter and } \\
\text { spores of puffball } \\
\text { mushroom, (guda } \\
\text { soko) } \\
2 \text { resin, salve, mix } \\
\text { with beewax, olive } \\
\text { oil, butter }\end{array}$ & $\begin{array}{l}\text { wound } 1,2 \\
\text { foot-and-mouth } \\
\text { disease } 1\end{array}$ & cattle & 0,04 & 0,09 & 0,02 & 0,09 & \\
\hline $\begin{array}{l}\text { Pinus sylvestris var hamata } \\
\text { Steven } \\
\text { syn: Pinus sosnowskyi Nakai } \\
\text { (CK, SO 77, 447) }\end{array}$ & $\begin{array}{l}\text { pichvi (Geo), kataris } \\
\text { pichvi (Geo), sosna } \\
\text { (Rus), katari } \\
\text { (Geo), çam, sarıçam } \\
\text { (Tur), katari, pichvi } \\
\text { (Geo) }\end{array}$ & 1 young seed cones & fodder 1 & pig & 0,02 & - & 0,02 & - & $\begin{array}{l}5,15 \text { (wound, } \\
\text { insect repellent) }\end{array}$ \\
\hline
\end{tabular}




\begin{tabular}{|c|c|c|c|c|c|c|c|c|c|}
\hline \multicolumn{10}{|l|}{ PLANTAGINACEAE } \\
\hline $\begin{array}{l}\text { Plantago major L. } \\
\text { (CK, SO 515, 535) } \\
(\mathrm{CK}, \mathrm{SO} 53,1563)\end{array}$ & $\begin{array}{l}\text { mravaldzargya (Geo), } \\
\text { podoroznik (Rus), } \\
\text { yezan lezu (Arm), bağa } \\
\text { yaprağı, yedi damar } \\
\text { (Tur), ohte damar, şvit } \\
\text { damari, belhavıs, } \\
\text { belhebis (Kur), yara } \\
\text { yaprağı, balarzarghva, } \\
\text { sinirli ot, damarlı ot } \\
\text { (Tur), belhebis }\end{array}$ & $\begin{array}{l}1 \text { entire plant, } \\
\text { decoction in water, } \\
\text { internally } \\
2 \text { leaves, poultice, } \\
\text { externally }\end{array}$ & $\begin{array}{l}\text { diarrhea } 1 \\
\text { wound } 2\end{array}$ & cattle & 0,02 & 0,01 & 0,02 & 0,01 & 15 (abscess, wound) \\
\hline \multicolumn{10}{|l|}{ POACEAE } \\
\hline $\begin{array}{l}\text { Phragmites australis (Cav.) } \\
\text { Trin ex Steud. } \\
\text { (CK, SO 63) }\end{array}$ & $\begin{array}{l}\text { gamuş, kamış, saz otu } \\
\text { (Tur) }\end{array}$ & 1 aerial parts & fodder 1 & cattle & 0,02 & - & 0,02 & - & \\
\hline \multicolumn{10}{|l|}{ POLYGONACEAE } \\
\hline $\begin{array}{l}\text { Polygonum aviculare L. } \\
\text { (CK, SO 300) }\end{array}$ & $\begin{array}{l}\text { matitela (Geo), gusina } \\
\text { gashka, cancar (Arm), } \\
\text { gorets sporish (Rus), } \\
\text { kuş ekmeği, kuş otu, } \\
\text { kuş pancarı, kuş } \\
\text { pepeği, kuş pepesi, } \\
\text { madımak, madımalak } \\
\text { (Tur), matitel (Geo), } \\
\text { pencer, telce (Tur) }\end{array}$ & 1 aerial parts & fodder 1 & $\begin{array}{c}\text { cattle } \\
\text { chicken } \\
\text { duck }\end{array}$ & 0,07 & - & 0,07 & - & 5 \\
\hline $\begin{array}{l}\text { Polygonum carneum K Koch } \\
\text { syn: Polygonum bistorta subsp } \\
\text { carneum Coode \& Cullen } \\
\text { (CK, SO 68) }\end{array}$ & $\begin{array}{l}\text { dvaluri (Geo), dvalura } \\
\text { (Geo), çayır pancarı, } \\
\text { dağ pancarı, kızılcık } \\
\text { pancarı, pancar otu, } \\
\text { pazı pancarı, pencar, } \\
\text { yabani pancar, yayla } \\
\text { lahanası, yayla pancarı } \\
\text { (Tur), ğali, tiphala, } \\
\text { dvaluri (Geo), yaylaşi } \\
\text { luku (Laz) }\end{array}$ & 1 aerial parts & $\begin{array}{l}\text { fodder } 1 \\
\text { give easy birth } 1\end{array}$ & cattle & 0,09 & - & 0,09 & - & \\
\hline
\end{tabular}




\begin{tabular}{|c|c|c|c|c|c|c|c|c|c|}
\hline $\begin{array}{l}\text { Polygonum cognatum Meisn. } \\
\text { syn: Polygonum alpestre } \\
\text { C.A.Mey. } \\
\text { (FP-SO 72) }\end{array}$ & $\begin{array}{l}\text { matitela (Geo), cancar } \\
\text { (Arm), madımak (Tur), } \\
\text { kuş ekmeği, kuş } \\
\text { pepesi, kuş otu, kuş } \\
\text { pancarı (Tur), matitel } \\
\text { (Geo), paluği cuçki } \\
\text { (Kur) }\end{array}$ & 1 leaves, in yoghurt & fodder 1 & gosling & - & 0,01 & - & 0,01 & \\
\hline $\begin{array}{l}\text { Rumex alpinus L } \\
\text { (CK, SO 70) } \\
\text { (CK, SO 654) }\end{array}$ & $\begin{array}{l}\text { ghvalo (Geo),poliyo, } \\
\text { gvalo, öküz tırşosu, } \\
\text { yabani evelik, palak } \\
\text { yaprağı (Tur) } \\
\end{array}$ & 1 aerial parts & fodder $\mathbf{1}$ & cattle & 0,02 & 0,01 & 0,02 & 0,01 & 2 \\
\hline $\begin{array}{l}\text { Rumex crispus L. } \\
\text { (CK, SO 654, 776) }\end{array}$ & $\begin{array}{l}\text { aveluk (Arm), ghvalo } \\
\text { (Geo), övelik,evelik } \\
\text { evelek (Tur), ghvalo } \\
\text { (Geo) }\end{array}$ & 1 aerial parts & fodder 1 & cattle & - & 0,01 & - & 0,01 & 5 (antidiarrheal) \\
\hline $\begin{array}{l}\text { Rumex sp. } \\
\text { (CK, SO 1511) }\end{array}$ & $\begin{array}{l}\text { kokomzhava (Geo), } \\
\text { ghvalo (Geo), ghvalo, } \\
\text { peçek, palak, poliyo, } \\
\text { kukumjava }\end{array}$ & 1 aerial parts & fodder 1 & $\begin{array}{l}\text { goose } \\
\text { cattle }\end{array}$ & 0,02 & 0,09 & 0,02 & 0,09 & \\
\hline \multicolumn{10}{|l|}{ POLYPODIACEAE } \\
\hline $\begin{array}{l}\text { Pteridium aquilinum (L.) } \\
\text { (CK, SO 91, 514) }\end{array}$ & $\begin{array}{l}\text { etsris gvimra (Geo), } \\
\text { tabela, bilançro (Laz) }\end{array}$ & $\begin{array}{l}1 \text { roots, dry in fodder } \\
2 \text { aerial parts, dried }\end{array}$ & $\begin{array}{l}\text { indigestion 1, } 2 \\
\text { fodder } 2\end{array}$ & cattle & 0,04 & 0,01 & 0,04 & 0,01 & $\begin{array}{l}15 \text { (urinary disease, } \\
\text { analgesic) }\end{array}$ \\
\hline \multicolumn{10}{|l|}{ RANUNCULACEAE } \\
\hline Helleborus orientalis Lam. & $\begin{array}{l}\text { kharadzira } \\
\text { (Geo), halazina, dabak } \\
\text { otu (Tur) }\end{array}$ & $\begin{array}{l}1 \text { roots, raw in fodder } \\
2 \text { roots, hang on } \\
\text { throat of animals } \\
3 \text { entire plant, } \\
\text { decoction in water, } \\
\text { externally }\end{array}$ & $\begin{array}{l}\text { inflammation 1,2 } \\
\text { foot-and-mouth } \\
\text { disease } 3\end{array}$ & cattle & - & 0,04 & - & 0,03 & $\begin{array}{l}2 \text { (wound), 3, 4, } 12 \text { (bad } \\
\text { liquid, gas, wounds), } 9 \\
\text { (cleans blood of cattle), } 15 \\
\text { (antipyretic, analgesic, } \\
\text { sunstroke, joint ailments, } \\
\text { cold, diarrhea, mastitis, } \\
\text { keratitis, malaria, edema, } \\
\text { aphrodisiac, animal } \\
\text { weekness, immuno } \\
\text { stimulant) }\end{array}$ \\
\hline \multicolumn{10}{|l|}{ RHAMNACEAE } \\
\hline $\begin{array}{l}\text { Paliurus spina-christi Mill. } \\
(\mathrm{CK}, \mathrm{SO} 8,18)\end{array}$ & karadiken (Tur) & $\begin{array}{l}1 \text { branches, hang on } \\
\text { animals } \\
\text { forehead }\end{array}$ & belief (evil eye) 1 & cattle & - & 0,03 & - & 0,03 & 15 (mastitis) \\
\hline
\end{tabular}




\begin{tabular}{|c|c|c|c|c|c|c|c|c|c|}
\hline \multicolumn{10}{|l|}{ ROSACEAE } \\
\hline $\begin{array}{l}\text { Alchemilla } s p . \\
\text { (CK, sO 33, 519) }\end{array}$ & $\begin{array}{l}\text { marmuchi (Geo), yağlı } \\
\text { ot, sütlü ot, ayı } \\
\text { pençesi, aslan pençesi } \\
\text { (Tur) }\end{array}$ & $\begin{array}{l}1 \text { aerial parts, in } \\
\text { fodder }\end{array}$ & $\begin{array}{l}\text { increase milk } \\
\text { production } 1\end{array}$ & cattle & 0,02 & 0,04 & 0,02 & 0,04 & 1,15 \\
\hline $\begin{array}{l}\text { Crataegus monogyna Jacq } \\
\text { syn: Crataegus } \\
\text { kyrtostyla Fingerh. } \\
\text { (CK, SO 1784) }\end{array}$ & $\begin{array}{l}\text { tsiteli kuneli (Geo), } \\
\text { kirkat, kurkantela } \\
\text { (Geo), alucha (Arm), } \\
\text { kırkat, alıç (Tur), at } \\
\text { götü }\end{array}$ & $\begin{array}{l}1 \text { branches, hang on } \\
\text { animals' forehead }\end{array}$ & belief (evil eye) 1 & cattle & - & 0,01 & - & 0,01 & $\begin{array}{l}15 \text { (gastrointestinal, } \\
\text { reproductive disease, } \\
\text { snake bite) }\end{array}$ \\
\hline $\begin{array}{l}\text { Malus montana Uglitzk. } \\
\text { (CK, SO 445) }\end{array}$ & $\begin{array}{l}\text { veluri vashli (Geo), acı } \\
\text { elma, piç elma, kına } \\
\text { tura, meşe elması, } \\
\text { yabani elma (Tur) }\end{array}$ & $\begin{array}{l}1 \text { branches, hang on } \\
\text { animals } \\
\text { forehead }\end{array}$ & belief (evil eye) 1 & cattle & 0,04 & 0,12 & 0,04 & 0,12 & $\begin{array}{l}15 \text { (difficulty of birth, } \\
\text { increase milk secretion) }\end{array}$ \\
\hline $\begin{array}{l}\text { Prunus avium (L.) L. } \\
\text { syn: Cerasus avium (L.) } \\
\text { Moench } \\
\text { (CK, SO 33, 859, 1061, 1445, } \\
1662)\end{array}$ & $\begin{array}{l}\text { veluri bali, gareuli bali } \\
\text { (Geo), yabani kiraz, } \\
\text { bali, acı kiraz (Tur), mır } \\
\text { kirazı }\end{array}$ & $\begin{array}{l}1 \text { branches, hang on } \\
\text { animals' forehead }\end{array}$ & belief (evil eye) 1 & cattle & - & 0,03 & - & 0,03 & $\begin{array}{l}1 \text { (diarrhea), } 15 \text { (intestinal } \\
\text { disease) }\end{array}$ \\
\hline $\begin{array}{l}\text { Prunus divaricata Ledeb. } \\
\text { (CK, SO 453, 459, 464) }\end{array}$ & $\begin{array}{l}\text { tkemali (Geo), cancur } \\
\text { (Arm), sarol, temal, } \\
\text { tkemali (Geo), muş, } \\
\text { çançur, yabani erik } \\
\text { (Tur) }\end{array}$ & 1 fruits, raw & swollen stomach 1 & cattle & 0,02 & - & 0,02 & - & $\begin{array}{l}15 \text { (wound, } \\
\text { gastrointestinal parasite) }\end{array}$ \\
\hline $\begin{array}{l}\text { Pyrus communis L. } \\
\text { (CK, SO 450, 462) }\end{array}$ & $\begin{array}{l}\text { panta (Geo),yaban } \\
\text { armudu (Tur), panta }\end{array}$ & $\begin{array}{l}1 \text { branches, hang on } \\
\text { animals' forehead }\end{array}$ & belief (evil eye) 1 & cattle & 0,02 & - & 0,02 & - & \\
\hline $\begin{array}{l}\text { Rosa spinosissima L. } \\
\text { syn: Rosa } \\
\text { pimpinellifolia } \mathrm{L} \\
(\mathrm{CK}, \mathrm{SO} 24,1019,1024,1529 \\
1669,1711)\end{array}$ & $\begin{array}{l}\text { shavi askili (Geo), } \\
\text { masur (Arm), shipovnik } \\
\text { (Rus), kara tiken, kara } \\
\text { esgül, kara kuşburnu } \\
\text { (Tur), şilan (Kur) } \\
\end{array}$ & $\begin{array}{l}1 \text { branches, hang on } \\
\text { animals' forehead }\end{array}$ & belief (evil eye) 1 & cattle & - & 0,01 & - & 0,01 & \\
\hline Sibbaldia parviflora Willd. & yağlı ot (Tur) & $\begin{array}{l}1 \text { aerial parts with } \\
\text { flowers, in fodder }\end{array}$ & $\begin{array}{l}\text { increase milk } \\
\text { production } 1\end{array}$ & cattle & - & 0,03 & - & 0,03 & \\
\hline $\begin{array}{l}\text { Sorbus aucuparia L. } \\
\text { syn: Sorbus } \\
\text { caucasigena Kom ex Gatsch. } \\
\text { (CK, SO 75, 456) } \\
\text { (CK, SO 1459, 1591, 1660) }\end{array}$ & $\begin{array}{l}\text { mchknavi (Geo), } \\
\text { çıknavi, cinav, ayı } \\
\text { kakası (Tur) }\end{array}$ & $\begin{array}{l}1 \text { young branches } \\
\text { with leaves, in fodder } \\
2 \text { fruits, raw } \\
3 \text { young branches } \\
\text { with leaves, } \\
\text { decoction in water, } \\
\text { internally }\end{array}$ & $\begin{array}{l}\text { increase milk } \\
\text { production } 1 \\
\text { fodder } 1,2 \\
\text { worm } 3 \\
\text { stomach-ache } 3\end{array}$ & $\begin{array}{l}\text { chicken } \\
\text { cattle } \\
\text { calf }\end{array}$ & 0,16 & 0,04 & 0,16 & 0,03 & \\
\hline
\end{tabular}




\begin{tabular}{|c|c|c|c|c|c|c|c|c|c|}
\hline SALICACEAE & & & & & & & & & \\
\hline $\begin{array}{l}\text { Salix caprea L. } \\
\text { (CK, SO 82, 98, 506, 522) } \\
\text { (CK, SO 1034) }\end{array}$ & $\begin{array}{l}\text { mdgnali (Geo), tsitsela } \\
\text { (Geo), mdgnali (Geo), } \\
\text { yabani söğüt, tüylü } \\
\text { sögüt (Tur) }\end{array}$ & $\begin{array}{l}1 \text { young branches } \\
\text { with leaves }\end{array}$ & fodder 1 & cattle & 0,02 & 0,01 & 0,02 & 0,01 & 3,4 \\
\hline $\begin{array}{l}\text { Salix sp. } \\
\text { (CK, SO 208) }\end{array}$ & $\begin{array}{l}\text { tiriphi (Geo), dzetsni } \\
\text { (Geo), söğüt, köy } \\
\text { söğüdü, meşe söğüdü, } \\
\text { su söğüdü (Tur) }\end{array}$ & $\begin{array}{l}1 \text { young branches } \\
\text { with leaves }\end{array}$ & fodder 1 & cattle & 0,04 & - & 0,04 & - & $\begin{array}{l}15 \text { (constipation, } \\
\text { increase milk secretion) }\end{array}$ \\
\hline \multicolumn{10}{|l|}{ SANTALACEAE } \\
\hline $\begin{array}{l}\text { Viscum album L. } \\
\text { (FP-SO 5) }\end{array}$ & $\begin{array}{l}\text { phitri (Geo), pintri, fitri } \\
\text { (Geo), çaabu (Laz) }\end{array}$ & $\begin{array}{l}1 \text { entire plant, in } \\
\text { fodder } \\
2 \text { entire plant, } \\
\text { infusion in water, } \\
\text { internally }\end{array}$ & $\begin{array}{l}\text { get easy birth } 1 \\
\text { fodder } 1 \\
\text { cough } 2\end{array}$ & cattle & 0,09 & 0,07 & 0,09 & 0,07 & $\begin{array}{l}10 \text { (diarrhea), } 11,15 \\
\text { (respiratory disease, } \\
\text { increasing milk secretion, } \\
\text { cough, endoparasites, } \\
\text { diarrhea, gastrointestinal } \\
\text { parasites) }\end{array}$ \\
\hline \multicolumn{10}{|l|}{ SAPINDACEAE } \\
\hline $\begin{array}{l}\text { Acer campestre L. } \\
\text { (CK, SO 79) }\end{array}$ & $\begin{array}{l}\text { leki } \\
\text { nekerchkhali (Geo),lek }\end{array}$ & $\begin{array}{l}1 \text { young branches } \\
\text { with } \\
\text { leaves }\end{array}$ & fodder 1 & cattle & 0,09 & 0,01 & 0,09 & 0,01 & \\
\hline $\begin{array}{l}\text { Acer heldreichii subsp } \\
\text { trautvetteri (Medw.) } \\
\text { A.E.Murray } \\
\text { (CK, SO 444) }\end{array}$ & $\begin{array}{l}\text { leki (Geo), } \\
\text { nekerchkhali (Geo), eki } \\
\text { (Geo) }\end{array}$ & \begin{tabular}{|l}
11 young branches \\
with leaves \\
2 branches, hang on \\
animals' forehead \\
\end{tabular} & $\begin{array}{l}\text { fodder } 1 \\
\text { belief (evil eye) } 2\end{array}$ & cattle & 0,02 & 0,05 & 0,02 & 0,05 & \\
\hline $\begin{array}{l}\text { Acer platanoides L. } \\
\text { (CK, SO 1481) }\end{array}$ & $\begin{array}{l}\text { leki, nekerchkhali } \\
\text { (Geo), leki, korapi } \\
\text { (Geo) }\end{array}$ & $\begin{array}{l}1 \text { young branches } \\
\text { with leaves }\end{array}$ & fodder 1 & cattle & 0,02 & - & 0,02 & - & \\
\hline \multicolumn{10}{|l|}{ SCROPHULARICEAE } \\
\hline $\begin{array}{l}\text { Verbascum spp. } \\
\text { (CK, SO 1547, 1592) }\end{array}$ & $\begin{array}{l}\text { marjerk, mavuljak, } \\
\text { öküzkuyruğu (Tur) }\end{array}$ & $\begin{array}{l}1 \text { aerial parts with } \\
\text { flowers, infusion in } \\
\text { water, internally } \\
2 \text { aerial parts with } \\
\text { flowers, infusion in } \\
\text { water, externally } \\
\end{array}$ & $\begin{array}{l}\text { worms } 1 \\
\text { lice } 2\end{array}$ & $\begin{array}{l}\text { sheep } \\
\text { cattle }\end{array}$ & - & 0,03 & - & 0,04 & $\begin{array}{l}14 \text { (worms), } 15 \text { (injuries, } \\
\text { antiparasitic, wound, cold, } \\
\text { diarrhea, worms) }\end{array}$ \\
\hline \multicolumn{10}{|l|}{ TYPHACEAE } \\
\hline Typha sp. & cil otu, çil (Tur) & 1 aerial parts & fodder 1 & cattle & - & 0,01 & - & 0,01 & \\
\hline \multicolumn{10}{|l|}{ ULMACEAE } \\
\hline Ulmus glabra Huds. & $\begin{array}{l}\text { tela (Geo), kara ağaç, } \\
\text { karağacı, moşi, } \\
\text { morkan ağacı (Tur) }\end{array}$ & $\begin{array}{l}1 \text { young branches } \\
\text { with leaves }\end{array}$ & $\begin{array}{l}\text { fodder } 1 \\
\text { increase milk } \\
\text { production } 1\end{array}$ & cattle & - & 0,04 & - & 0,04 & 10 \\
\hline
\end{tabular}




\begin{tabular}{|c|c|c|c|c|c|c|c|c|c|}
\hline URTICACEAE & & & & & & & & & \\
\hline $\begin{array}{l}\text { Urtica dioica L. } \\
\text { CK, SO 510) } \\
\text { (CK, SO 1526) }\end{array}$ & $\begin{array}{l}\text { krapiva (Rus), } \\
\text { chinchari (Geo), } \\
\text { aghinch, yeghinch } \\
\text { (Arm), kecan, ısırgan } \\
\text { (Tur), çinçar, cincar } \\
\text { (Geo), ağinç (Arm), } \\
\text { gezgezik (Kur), dıçkıci } \\
\text { (Laz) }\end{array}$ & $\begin{array}{l}1 \text { aerial parts } \\
2 \text { aerial parts, mix } \\
\text { with Polygonum } \\
\text { bistorta, Symphytum, } \\
\text { Heracleum and boil } \\
\text { them before mix in } \\
\text { fodder }\end{array}$ & fodder $\mathbf{1}, 2$ & $\begin{array}{l}\text { cattle } \\
\text { pig } \\
\text { chicken } \\
\text { goose }\end{array}$ & 0,07 & 0,04 & 0,02 & 0,04 & $\begin{array}{l}2,3,4,5,10,15 \\
\text { (abscess, wound) }\end{array}$ \\
\hline Urtica urens L. & yabani ısırgan (Tur) & 1 aerial parts & fodder 1 & turkey & - & 0,01 & - & 0,01 & $\begin{array}{l}15 \text { (reproductive disease, } \\
\text { dermal disease, wound) }\end{array}$ \\
\hline
\end{tabular}

a "CK, SO (number)": Collection number of species "FP-SO (number)": Field photo number of the specimen Bold numbers indicate specimens from Georgia, the others from Turkey.

${ }^{b}$ Recorded local names of species in both countries during the fieldwork Names written in Italics are from Turkey, the rest are from Georgia Arm: Armenian, Geo:Georgian, Kur: Kurdish, Laz: Laz language, Tur:Turkish, Rus: Russian.

c Each different number $(1,2,3 \ldots)$ indicates a plant part used in a remedy

d Numbers written in bold are shared reports between participants in both countries, Italics are associated with the recipes from Turkey, the rest are from Georgia Each number $(1,2,3 \ldots)$ in the use category match with the plant parts used.

e Cultural importance value (Cl) of species in Georgia (Geo) and in Turkey (Tur) "n" indicates the participant number of each country.

f Relative requency of citation (RFC) values of species in Georgia (Geo) and in Turkey (Tur).

g Numbers and its corresponding references: (1) Akbulut et al 2014, (2) Bussmann et al 2018, (3) Bussmann et al 2016a, (4) Bussmann et al 2016b, (5) Bussmann 2017,(6) Güneş \& Özhatay 2011, (7) Macit \& Köse 2015, (8) Sezik et al 1997, (9) Bussmann et al 2020b, (10) Saraç et al 2013, (11) Bussmann et al 2020a, (12) Bussmann et al 2017 (13) Sezik et al 1991,(14) Altundağ 2009, (15) Eraslan \& Kültür 2019 


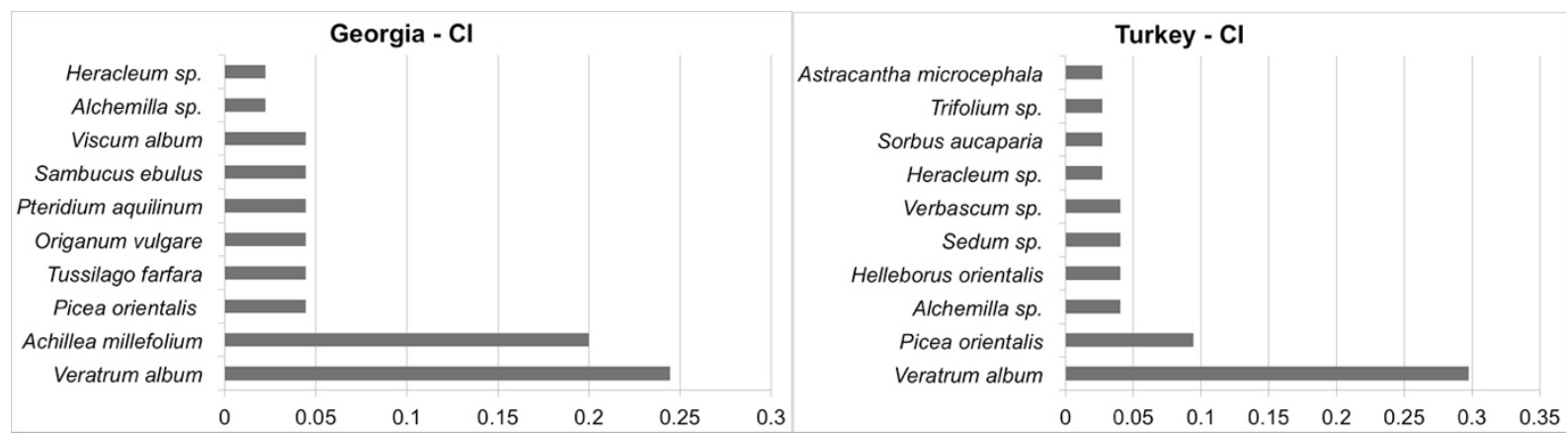

Figure 3. Cultural importance $(\mathrm{Cl})$ index of the 10 most important species used in ethnoveterinary medicine in each country.

Table 2. Comparison of UR (\%) for plant parts used, preparations, and applications for ethnoveterinary purposes in Georgia and in Turkey. ${ }^{*}$

\begin{tabular}{|c|c|c|c|c|c|}
\hline Plant parts used & $\begin{array}{c}\text { UR (\%) } \\
\text { Geo }\end{array}$ & $\begin{array}{l}\text { UR (\%) } \\
\text { Tur }\end{array}$ & Preparations & $\begin{array}{c}\text { UR (\%) } \\
\text { Geo }\end{array}$ & $\begin{array}{c}\text { UR (\%) } \\
\text { Tur }\end{array}$ \\
\hline roots & $23,53 \%$ & $41,94 \%$ & decoction in water/milk & $52,94 \%$ & $48,39 \%$ \\
\hline aerial parts with flowers & $29,41 \%$ & $12,90 \%$ & dried or raw in fodder & $19,61 \%$ & $17,74 \%$ \\
\hline aerial parts & $15,69 \%$ & $20,97 \%$ & poultice or plaster & $5,88 \%$ & $25,81 \%$ \\
\hline resin & $3,92 \%$ & $11,29 \%$ & infusion in water & $21,57 \%$ & $6,45 \%$ \\
\hline entire plant & $9,80 \%$ & $1,61 \%$ & hang on throat of animal & - & 1,61\% \\
\hline $\begin{array}{l}\text { leaves } \\
\text { young branches with }\end{array}$ & $5,88 \%$ & $4,84 \%$ & Applications & Geo & Tur \\
\hline leaves & $3,92 \%$ & $4,84 \%$ & internally & $76,47 \%$ & $29,03 \%$ \\
\hline fruits & $3,92 \%$ & $0,00 \%$ & externally & $23,53 \%$ & $70,97 \%$ \\
\hline flowers & $1,96 \%$ & $0,00 \%$ & & & \\
\hline inner barks & - & $1,61 \%$ & & & \\
\hline
\end{tabular}

* Note that the information (words) in each row do not match with each other (See in Table 1 for the preparation and application of each plant part). Information was ranked in accordance of importance based on mean UR (\%) values of the countries.
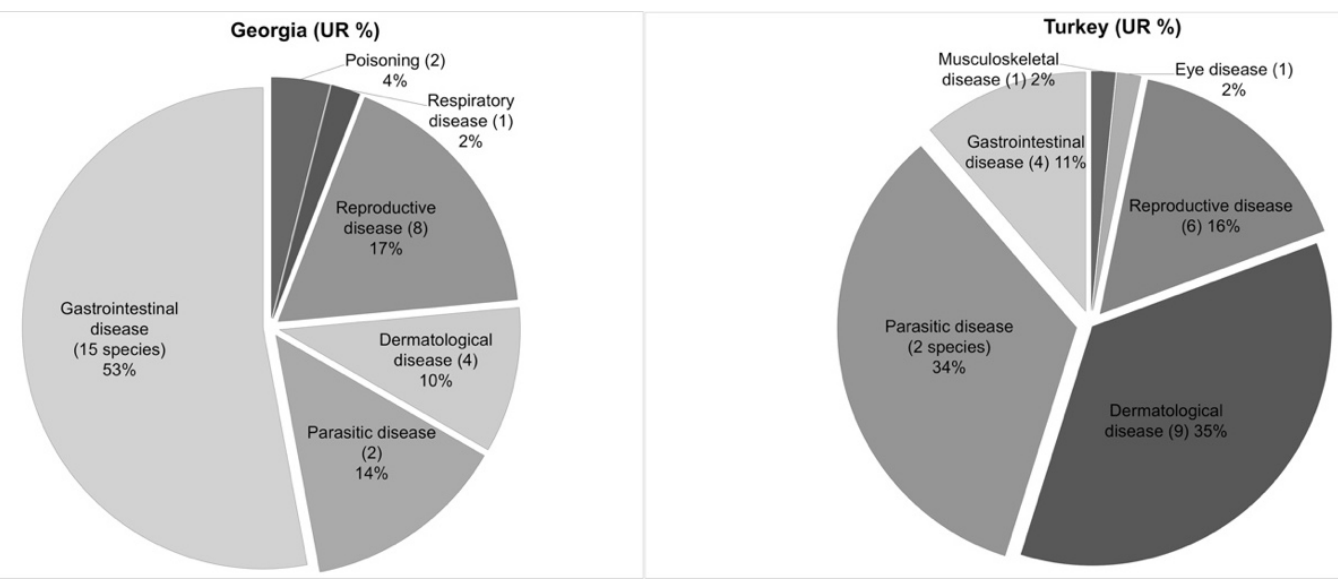

Figure 4. Percentage of use reports (UR\%) and number of species for each ethnoveterinary use category in each country.

The most common gastrointestinal complaints and their treatments differ in both countries. In Georgia, giving a water infusion of Achillea millefolium aerial parts with flowers to cattle is a cure for stomachache and diarrhea, whereas in Turkey giving a water infusion of Verbascum sp. aerial part or a water 
decoction of Sorbus aucuparia young branches with leaves are used as wormer. The use of Verbascum with same purpose and application was also reported in Turkey (Altundağ 2009, Erarslan \& Kültür 2019).

Related to dermatological problems, Picea orientalis is the most important plant for wound healing in animals in both countries. Macerated resin of Picea orientalis, locally called "pisi", is mixed with butter and spores of puffball mushroom, and applied as a plaster for any kind of wound and foot-and-mouth disease in both countries. One unique report from Turkey also describes using it in a homemade wound healing salve, a mixture of Picea resin, beeswax, butter and olive oil, which is used for foot-and-mouth disease.

Table 3. The most cited species for ethnoveterinary, fodder and against evil eye use in each country.

\begin{tabular}{|c|c|c|}
\hline & $\begin{array}{c}\text { Georgia } \\
\text { (UR) }\end{array}$ & $\begin{array}{c}\text { Turkey } \\
\text { (UR) }\end{array}$ \\
\hline \multicolumn{3}{|c|}{ Fodder } \\
\hline Trifolium spp. & 9 & 18 \\
\hline Rumex spp. & 2 & 9 \\
\hline Acer spp. & 7 & 4 \\
\hline Ruscus colhicus & 2 & 7 \\
\hline Quercus spp. & 3 & 5 \\
\hline Sambucus ebulus & 1 & 6 \\
\hline Viscum album & 2 & 5 \\
\hline Urtica dioica & 3 & 4 \\
\hline Polygonum spp. & 6 & 1 \\
\hline Sorbus aucuparia & 6 & 1 \\
\hline Capsella bursa-pastoris & - & 6 \\
\hline Taraxacum sp. & 1 & 5 \\
\hline Petasites sp. & 5 & 1 \\
\hline \multicolumn{3}{|c|}{ Belief (evil eye) } \\
\hline Malus montana & 2 & 9 \\
\hline Viburnum lantana & 4 & 6 \\
\hline \multicolumn{3}{|c|}{ Gastrointestinal disease } \\
\hline Achillea millefolium & 8 & 1 \\
\hline Veratrum album & 4 & - \\
\hline \multicolumn{3}{|c|}{ Dermatological disease } \\
\hline Picea orientalis & 2 & 7 \\
\hline Helleborus orientalis & - & 3 \\
\hline \multicolumn{3}{|c|}{$\begin{array}{r}\text { Parasitic disease } \\
\text { Pase }\end{array}$} \\
\hline Veratrum album & 6 & 20 \\
\hline \multicolumn{3}{|c|}{ Reproductive disease } \\
\hline Alchemilla sp. & 1 & 3 \\
\hline Heracleum sp. & 1 & 2 \\
\hline Tussilago farfara & 2 & 1 \\
\hline
\end{tabular}

A decoction of Astracantha microcephala root or whole Helleborus orientalis was also mentioned to cure foot-and-mouth disease in Turkey.

For parasitic diseases, Veratrum album was major plant mentioned for the treatment of lice and scabby in both countries. Sheep and cattle with scabies are bathed in the decoction of Veratrum album roots.
The extent of similar naming and use of Veratrum album roots against ectoparasites in the whole study regions presents the special cultural value of the species in the Caucasus. This appears to be related to consensus on therapeutic efficacy of the species to cure parasitic symptoms of cattle and sheep.

The other traditional ethnoveterinary knowledge and practices in the study area were related to reproductivity, respiratory, musculoskeletal and poisoning in livestock.

Raw use of Viscum album or Polygonum bistorta in fodder was mentioned to ease birth in Georgia. Alchemilla sp., Heracleum sp. and Tussilago farfara were mentioned to increase milk production in both countries. Decoction of Veratrum album roots was stated to cure mastitis in Turkey. In addition, Viscum album was mentioned for cough in Georgia. In Turkey, Trifolium spp. was mentioned for fracture. Regarding poisoning, tea of Berberis vulgaris branches with leaves, and roots of Sambucus ebulus in fodder are known as antidote in Georgia.

Among the wild plants used as fodder, Fabaceae, Polygonaceae and Asteraceae were most mentioned families in both countries. Trifolium spp. is the most widely used plant as fodder in both countries. Rumex spp., Ruscus colchicus, Sambucus ebulus, Capsella bursa-pastoris follows it in Turkey. While in Georgia, Acer spp., Polygonum spp., Sorbus aucuparia and Petasites sp. are preferred. Among them, collecting and adding aerial parts of Ruscus colchicus, Viscum album, Sambucus ebulus, and Sorbus aucuparia to cattle's fodder as nutraceutical appear to be specific to Adjara and Artvin.

Use of Ruscus colchicus as fodder for cattle has also been reported in Georgia (Bussmann et al. 2020b, Bussmann 2017). Ruscus colchicus was reported as an excellent food plant due to its benefits on high milk yield (Khidasheli \& Papunidze 2014). Shared ethnoveterinary knowledge and practices of the communities for this species called with the same local names might be related to the similar cultural background of the communities living in these regions.

The popularity of some species exclusively in Ardahan could be related to existence of variety of livestock in the region. For instance, Polygonum cognatum, Capsella bursa-pastoris, Rumex spp., and Tragopogon species were mentioned for raising geese in Ardahan. This tradition might contribute to the diversification of ethnoveterinary knowledge and practice in the study area. 


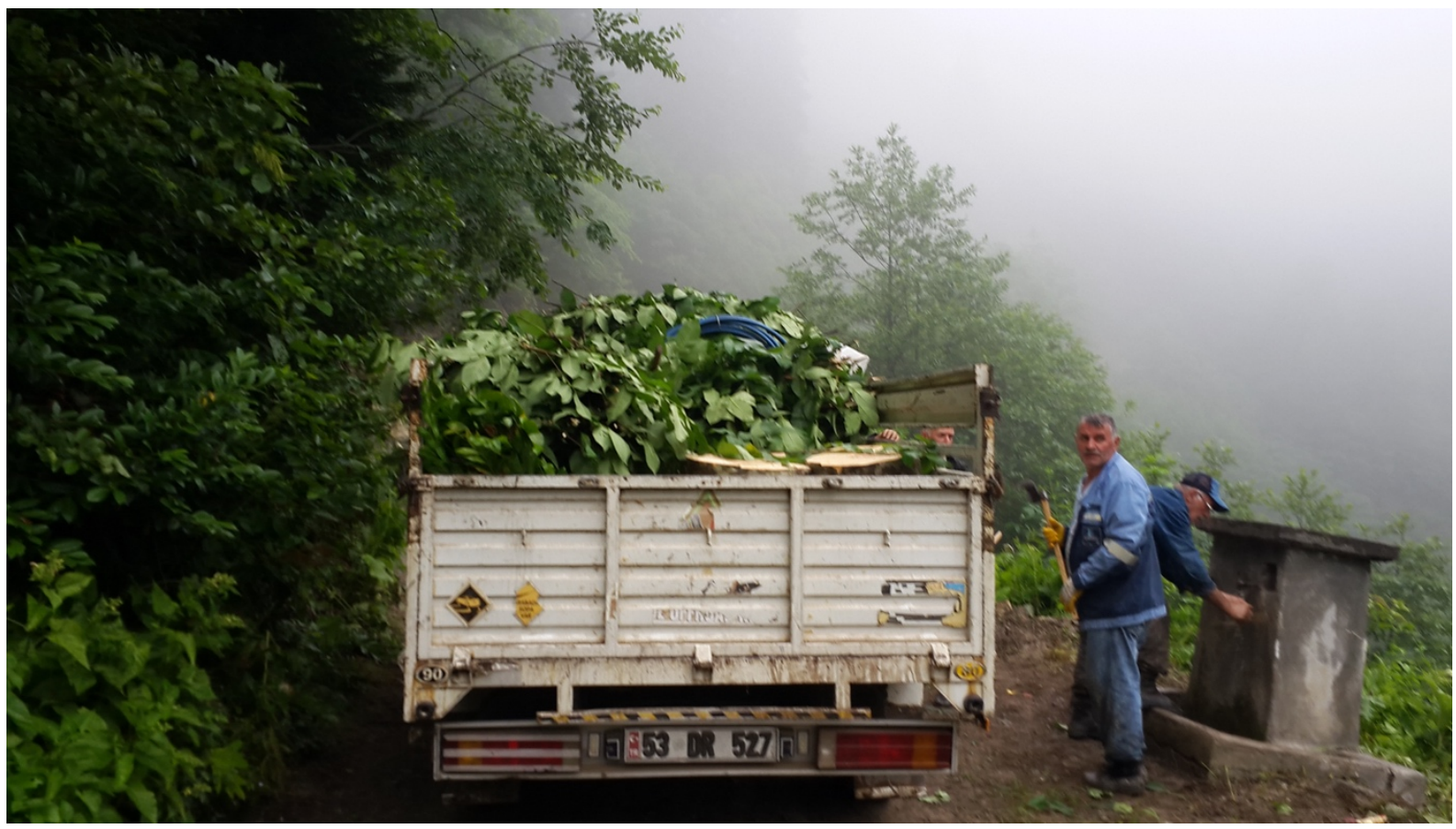

Figure 5. Young branches and leaves of trees and shrubs harvested to feed the cattle on the road to plateau in Artvin, Turkey.

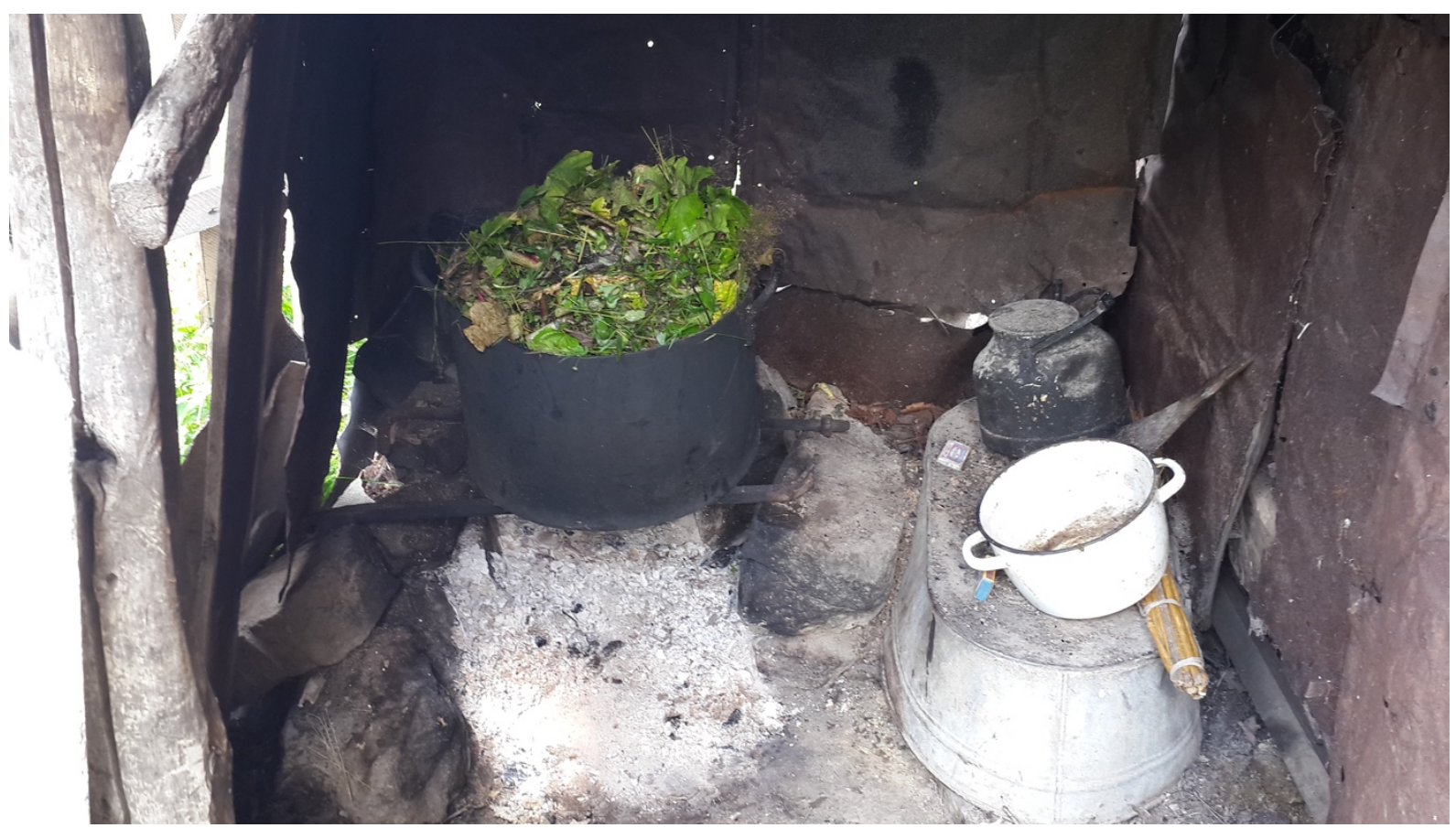

Figure 6. Animal fodder prepared by cooking mix wild plants in Adjara, Georgia

Some species have indirect veterinary uses for the well-being of livestock, such as those used as bedding to protect them against colds and serious diseases, and against evil eye. It was reported that the above-ground parts of Dryopteris filix-mas and Pteridium aquilinum species were covered on the floor of the barn to protect the animals from cold in Adjara and Artvin, and then used as fertilizer for vegetable gardens. Plants used against evil eye constitute $10 \%$ of the URs with 12 species in the study area. Viburnum lantana and Malus montana were the most mentioned species in both countries. It is believed that branches of these species hanged on cattle's forehead protect them from illnesses. The use of Viburnum lantana against evil eye in cattle has also been reported in Georgia (Bussmann et al. 
2020b, Bussmann 2017). Viburnum lantana is used mostly in Adjara and Artvin. This commonality might also be connected with similar cultural ties of the communities in Adjara and Artvin.

In sum, we found few difference in plants used in ethnoveterinary and fodder purposes between transhumant communities on both sides of GeorgiaTurkey border. The similarities may be related to the similar environmental conditions across the border or historical contact of the communities especially before the current position of the border was establish in 1921, or more likely the common cultural background of majority of the participants may have result in many similarities. They are mostly apparent between Artvin and Adjara where the participants have same mother language (Georgian), share common cultural background and having ongoing cultural ties.

\section{Conclusions}

The findings of this study suggest that pastoral way of life in the Western Lesser Caucasus still reflects living evidence of plant-based traditional ethnoveterinary knowledge and practices to support the health of livestock. We found few difference in plants used in ethnoveterinary between communities on both sides of Georgia Turkey border. There seems to be several plants documented in this study especially for gastrointestinal and parasitical disease that might be an alternative to modern veterinary drugs. The results of this study could be a base for future ethnoveterinary and animal feed research in the region. Since there is an ongoing abandonment of highlands and traditional practices, particular attention is suggested to be given to pastoral communities in future studies. We hope that this study will stimulate further ethnoveterinary study in Turkey, Georgia and in the Caucasus in order to document this valuable cultural heritage and to promote plant-based therapies and organic animal husbandry for the well-being of livestock and humans before it is totally replaced by modern pharmaceuticals.

\section{Declarations}

List of abbreviations: UR: Use-report $\mathrm{CI}$ : Cultural importance RFC: Relative frequency of citation

Ethics approval and consent to participate: All interviews conformed to the International Society of Ethnobiology's Code of Ethics. Scientific Research and Ethical Committee of Artvin Çoruh University in Turkey (Issue date-no: 14/02/2018-E.2708) approved the study.

Official research and plant collection permits were obtained from the Ministry of Forest and Water
Affairs (Issue date-no: 09/02/2018-E.8919), as well as from the Scientific Research and Ethical Committee of Artvin Çoruh University in Turkey (Issue date-no: 14/02/2018-E.2708). Ilia State University in Georgia was informed, and necessary official scientific research and travel permits were obtained from the Department of Land Border Protection of the Border Police of the Ministry of Internal Affairs of Georgia.

Consent for publication: The persons showed in images gave their consent for publication.

Competing interests: The authors declare that they have no competing interests.

Funding: In Georgia, Ilia State University partially funded the fieldworks of this study for three summer seasons (2016-2017-2018). GIZ Georgia also partially supported the fieldwork in 2017 as a scholarship to first author, Ceren Kazancı. Authors and people in crowd funding contributed to the rest. In Turkey, funding support for this study was provided from crowdfunding, the authors' own budgets and the first authors' parents. The funding sources did not have a role in the writing of the paper or the decision to submit the paper for publication.

Authors' contributions: C.K. (ceren.kazanci.1@iliauni.edu.ge) and S.O (soneroruc@gmail.com) designed the study, organized and conducted all the fieldwork and wrote all sections of the manuscript together. C.K. conducted the interviews, identified the plant specimens, constructed the database, analyzed the data and generated the table and map of the study area. M.M. (marine_mosulishvili@iliauni.edu.ge) partially participated in the fieldworks in Georgia, made advice and revisions during plant identifications and for the manuscript. All authors read and approved the manuscript.

\section{Acknowledgements}

This study was possible with the help of friendly people from Artvin, Ardahan, Adjara and Samtskhe Javakheti who shared their knowledge and experience. We are grateful to them for their willingness to interview and allocating significant time for us. Heartfelt thanks to all of them.

We would like to thank to our friends Nikita Ivanov, Shota Gelashvili, Nini Khuroshvili, Oli Lamm, Tamar Nadiradze, Sopo Kiknavelidze and Natalie Kuljanishvili for their translation of the interviews and field assistance during the surveys in Georgia. We also thank to our friends Zeynep Türkmen, Nihan Dilşad Dağtaş, Kasım Kırlangıç, Ali Haydar Altuğ, Muharrem Çavuşoğlu, Birsen Civelek, Utkan Bugay, Bilgen Kazancı and Çağla Kazancı for their valuable assistance and support during our fieldworks in Turkey. Many thanks to Prof. Özgür Eminağaoğlu and Dr. Hayal Akyıldırım Beğen for providing us a 
work environment in the Herbarium of Artvin Çoruh University in Turkey and for their help during identification of the plant specimens. Thanks to Çağatay Altın and Nature Conservation and National Park Branch of Ardahan for their concerns during our fieldwork in Turkey. Moreover, many thanks to Dr. Temur Vasadze, Dr. Nino Memiadze and the staff of the Batumi Botanical Garden, Goderdzi Alpine Botanical Garden; Dr. Manana Khutsishvili, Eto Svanidze and the staff of the National Herbarium of Georgia, Javakheti Protected Areas Administration and Border police and army in Georgia. Many thanks to Prof. Zaal Kikvidze for his interest and kind support during funding applications in Georgia and to all funders including hundreds of nature and culture lovers who valued and made precious contributions to our study with their small drops via crowdfunding. We are also indebted to Dr. Füsun Ertuğ for her longtermed encouragement, love and support for our ethnobotanical research.

\section{Literature cited}

Akbulut S, Özkan ZC. 2014. Traditional usage of some wild plants in Trabzon Region (Turkey). Kastamonu Üniversitesi Orman Fakültesi Dergisi 14(1):135-145.

Altundağ E. 2009. Iğdır ilinin (Doğu Anadolu Bölgesi) doğal bitkilerinin halk tarafından kullanımı. İstanbul Üniversitesi Sağlık Bilimleri Enstitüsü. PhD Thesis. (in Turkish)

Bartha SG, Quave CL, Balogh L, Papp N. 2015. Ethnoveterinary practices of Covasna County, Transylvania, Romania. Journal of Ethnobiology and Ethnomedicine 11(1):35.

Benítez G, González-Tejero MR, Molero-Mesa J. 2012. Knowledge of ethnoveterinary medicine in the Province of Granada, Andalusia, Spain. Journal of Ethnopharmacology 139(2):429-439.

Bussmann RW (ed). 2017. Ethnobotany of the Caucasus. Springer International Publishing, Stuttgart.

Bussmann RW, Paniagua Zambrana NY, Sikharulidze S, Kikvidze Z, Kikodze D, Tchelidze D, Batsatsashvili K, Hart RE. 2016a. Medicinal and food plants of Svaneti and Lechkhumi, Sakartvelo (Republic of Georgia), Caucasus. Medicinal and Aromatic Plants 5:266, doi:10.4172/21670412.1000266.

Bussmann RW, Paniagua Zambrana NY, Sikharulidze S, Kikvidze Z, Kikodze D, Tchelidze D, Batsatsashvili K, Hart RE. 2016b. A comparative ethnobotany of Khevsureti, Samtskhe-Javakheti, Tusheti, Svaneti, and Racha-Lechkhumi, Republic of
Georgia (Sakartvelo), Caucasus. Journal of Ethnobiology and Ethnomedicine 12:43, doi:10.1186/s13002-016-0110-2.

Bussmann RW, Paniagua Zambrana NY, Sikharulidze S, Kikvidze Z, Kikodze D, Tchelidze D, Batsatsashvili K, Hart RE. 2017. Ethnobotany of Samtskhe-Javakheti, Sakartvelo (Republic of Georgia), Caucasus. Indian Journal of Traditional Knowledge 16(1):7-24.

Bussmann RW, Paniagua Zambrana NY, Sikharulidze S, Kikvidze Z, Kikodze D, Tchelidze D, Batsatsashvili K, Hart RE. 2018. Unequal brothers Plant and fungal use in Guria and Racha, Sakartvelo (Republic of Georgia), Caucasus. Indian Journal of Traditional Knowledge 17(1):7-33.

Bussmann RW, Paniagua Zambrana, NY, Sikharulidze S, Kikvidze Z, Kikodze D, Tchelidze D, Khutsishvili M, Batsatsashvili K, Hart RE. 2020a. An ethnobotany of Kakheti and Kvemo Kartli, Sakartvelo (Republic of Georgia), Caucasus. Ethnobotany Research and Applications 19:1-27.

Bussmann RW, Paniagua Zambrana, NY, Sikharulidze S, Kikvidze Z, Darchidze M, Manvelidze Z, Ekhvaia J, Kikodze D, Khutsishvili M, Batsatsashvili K, Hart RE. 2020b. From the sea to the mountains-plant use in Adjara, Samegrelo and Kvemo Svaneti, Sakartvelo (Republic of Georgia), Caucasus. Ethnobotany Research and Applications 20:1-34.

Davis PH. 1965-1985. Flora of Turkey and the Aegean Islands (Vol.1-9). Edinburgh University Press. Edinburgh.

Davis PH, Miller RR, Tan K. 1988. Flora of Turkey and the Aegean Islands (Vol.10 Supplement I). Edinburgh University Press. Edinburgh.

Dinçer F. 1967. Türk folklorunda veteriner hekimliği üzerine araştırmalar. Doktora Tezi, Ankara Üniversitesi, A.Ü. Vet. Fak. Yay. No: 214, Ankara, 64 s.

Dinçer F. 1980. A report on the folklore activities and folk veterinary medicine in Turkey. Ankara Üniversitesi Veteriner Fakültesi Dergisi, 27(01.02).

Erarslan ZB, Kültür Ş. 2019. Ethnoveterinary medicine in Turkey: a comprehensive review. Turkish Journal of Veterinary and Animal Sciences 43(5):55-582.

Gagnidze RI. 2005. Vascular plants of Georgia: a nomenclatural checklist. Georgian Academy of Sciences.

Güner A, Özhatay N, Ekim T, Başer KHC. 2000. Flora of Turkey and the Aegean Islands Vol 11 
(Supplement II). Edinburgh University Press. Edinburgh.

Güner A, Aslan S, Ekim T, Vural M, Babaç MT. 2012. Türkiye Bitkileri Listesi (Damarlı Bitkiler) [Turkey Plant List (Vascular Plants)]. Nezahat Gökyiğit Botanik Bahçesi ve Flora Araştırmaları Derneği. (in Turkish).

Güneş F, Özhatay N. 2011. An ethnobotanical study from Kars (Eastern) Turkey. Biological Diversity and Conservation 4(1):30-41.

International Society of Ethnobiology. 2006. International Society of Ethnobiology Code of Ethics (with 2008 editions). http://ethnobiology.net/code-ofethics/

Komarov VL. 1968-2002. Flora of the U.S.S.R. Smithsonian Institution Libraries.

Macit MG, Köse YB. 2015. Medicinal plants used for folk medicine in Oltu (Erzurum/Turkey). Biological Diversity and Conservation 8(2):74-80.

Mayer M, Vogl CR, Amorena M, Hamburger M, Walkenhorst M. 2014. Treatment of organic livestock with medicinal plants: a systematic review of European ethnoveterinary research. Complementary Medicine Research 21(6):375-386.

McCorkle C.1986. An introduction to ethnoveterinary research and development. Journal of

Ethnobiology 6:129-149.

Oliveira M, Hoste H, Custódio L. 2020. A systematic review on the ethnoveterinary uses of Mediterranean salt-tolerant plants: exploring its potential use as fodder, nutraceuticals or phytotherapeutics in ruminant production. Journal of Ethnopharmacology 113464.

Oruç S, Kazancı C. 2018. Biocultural Diversity on the Border: The Yaylas of the Western Lesser Caucasus. Langscape Magazine, Terralingua 7(1). http://bit.ly/2JW7SBA

Özen R, Doğan G. 2017. Elazığ Yöresinde Veteriner Hekimliği Folklorunda Kullanılan Bitkisel İlaç Ham Maddeleri. Mersin Üniversitesi Tıp Fakültesi Lokman Hekim Tıp Tarihi ve Folklorik Tıp Dergisi 7(3):166177.

Pardo-de-Santayana M, Tardío J, Blanco E, Carvalho AM, Lastra JJ, San Miguel E, Morales R. 2007. Traditional knowledge of wild edible plants used in the northwest of the Iberian Peninsula (Spain and Portugal): a comparative study. Journal of Ethnobiology and Ethnomedicine 3(1):Article 27. https://doi.org/10.1186/1746-4269-3-27
Pieroni A, Howard P, Volpato G, Santoro RF. 2004. Natural remedies and nutraceuticals used in ethnoveterinary practices in inland southern Italy. Veterinary research communications 28(1):55-80.

Pieroni A, Giusti ME, De Pasquale C, Lenzarini C, Censorii E, Gonzáles-Tejero MR, Cristina Patricia Sánchez-Rojas PC, Ramiro-Gutiérrez JM, Skoula M, Johnson C, Sarpaki A, Della A, ParaskevaHadijchambi D, Hadjichambis A, Hmamouchi M, ElJorhi S, El-Demerdash M, El-Zayat M, Al-Shahaby O, Houmani Z, Scherazed M. 2006. CircumMediterranean cultural heritage and medicinal plant uses in traditional animal healthcare: a field survey in eight selected areas within the RUBIA project. Journal of ethnobiology and ethnomedicine 2(1):16.

Saraç DU, Özkan ZC, Akbulut S. 2013. Ethnobotanic features of Rize/Turkey province. Biological Diversity and Conservation 6(3):57-66.

Sezik E, Tabata M, Yesilada E, Honda G, Goto K, Ikeshiro Y. 1991. Traditional medicine in Turkey I. Folk medicine in northeast Anatolia. Journal of Ethnopharmacology 35(2):191-196. https://doi.org/10.1016/0378-8741(91)90072-L

Sezik E, Yeşilada E, Tabata M, Honda G, Takaishi Y, Fujita T, Tanaka T, Takeda Y. 1997. Traditional medicine in Turkey VIII. Folk medicine in east Anatolia; Erzurum, Erzincan, Ağrı, Kars, Iğdır provinces. Economic Botany 51(3):195-211. https://doi.org/10.1007/BF02862090

Sinmez ÇÇ, Aslım G, Yaşar A. 2018. An ethnoveterinary study on plants used in the treatment of dermatological diseases in Central Anatolia, Turkey. Journal of Complementary Medicine Research

\section{8(2):71-84. doi: 10.5455/jcmr.20180510044255}

Sinmez ÇÇ, Yaşar A. 2017. The use of herbal drugs in organic animal production: the case of ethnoveterinary medicine in Central Anatolia region. Turkish Journal of Agriculture - Food Science and Technology 5(13):1690-1695 (in Turkish with an abstract in English). doi: 10.24925/turjaf.v5i13.16901695.1536

Tardío J, Pardo-de-Santayana M. 2008. Cultural importance indices: a comparative analysis based on the useful wild plants of Southern Cantabria (Northern Spain). Economic Botany 62(1):24-39. https://doi.org/10.1007/s12231-007-9004-5

The Plant List. 2013. The Plant List, Version 1.1. http://www.theplantlist.org/ (01/01/2021)

Williams L, Zazanashvili N, Sanadiradze G, Kandaurov A. 2006. An ecoregional conservation 
plan for the Caucasus. WWF Caucasus Programme Office.

World Wildlife Fund. 2006. WildFinder: Online database of species distributions, ver. Jan-06. www.worldwildlife.org/WildFinder

Yipel M, Yipel FA, Tekeli IO, Güzel Y. 2017. Ethnoveterinary uses of medicinal plants in Mediterranean district, Turkey. Revista de ChimieBucharest 68(2):411-416. 